Historic, archived document

Do not assume content reflects current scientific knowledge, policies, or practices. 


\section{DESCMIPTION AND HYDROLOGIC ANALYSIS OF TWO SMAUL WATERSHEIS IN UTAH'S WASATCH MOUNTAINS}

FOR XEROX USE ONLY

PLEASE RETURN TO PROPER PLACE

INT-FILE CDPY
Robert S. Jolunston and Robert D. Doty

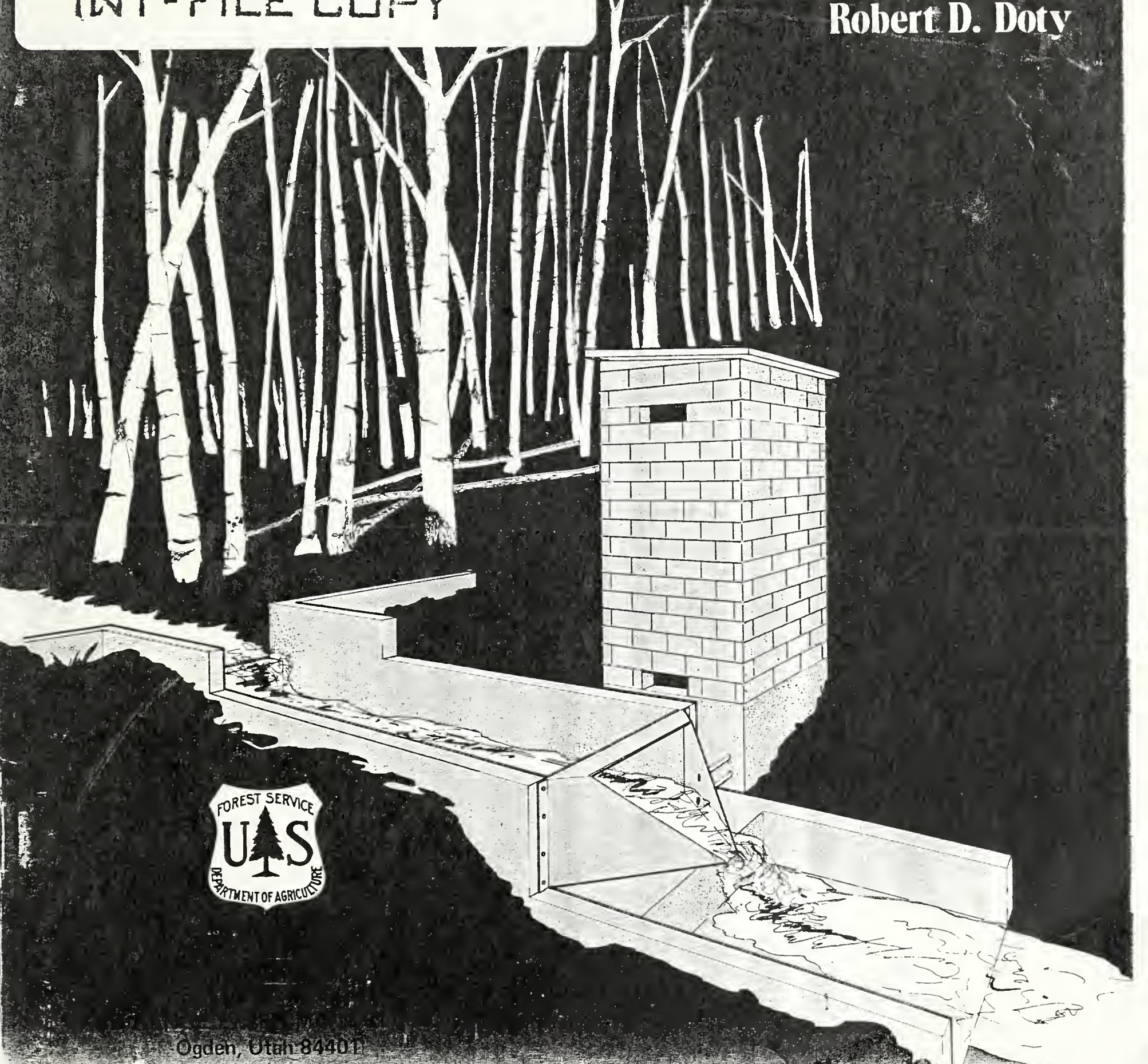




\section{AUTHORS}

ROBERT S. JOHNSTON is a Forest Hydrologist stationed at the Forestry Sciences Laboratory in Logan, Utah. He joined the staff of the Intermountain Station in 1964. He holds a B.S. degree in Forestry from Rutgers University and has done graduate study in the fields of Watershed Management and Hydrology at Colorado State University and Utah State University.

ROBERT D. DOTY, Associate Research Forester, has been employed by the Intermountain Station since 1964. He holds a B.S. degree in Forestry from the University of Idaho and an M.S. degree in Watershed Management from Utah State University.

The authors wish to acknowledge the assistance of David H. Crockett, Geologist, USDA Forest Service, Intermountain Region, who prepared the Soil Profile Descriptions and Soil Maps, and Dr. George B. Coltharp and Leslie A. Darling of Utah State University, Logan, for furnishing the Bacteriological Water Quality data. 
USDA Forest Service

Research Paper INT-127

July 1972

\title{
DESCRIPTION AND HYDROLOGIC ANALYSIS OF TWO SMALL WATERSHEDS \\ IN UTAH'S WASATCH MOUNTAINS
}

\author{
Robert S. Johnston \\ and \\ Robert D. Doty
}

INTERMOUNTAIN FOREST AND RANGE EXPERIMENT STATION

FOREST SERVICE

U.S. DEPARTMENT OF AGRICULTURE

OGDEN, UTAH 84401

ROBERT W. HARRIS, DIRECTOR 


\section{ABSTRACT}

The climate, geology, soils, and vegetation are included in a description of two small watersheds characteristic of the high-elevation aspen type of northern Utah. Precipitation, soil-water use, evapotranspiration, and quantity and quality of streamflow on these relatively undisturbed catchments are graphically illustrated and discussed. These data permit pretreatment calibration of these watersheds. This thorough inventory will allow a sensitive, multiresource analysis of planned treatments.

The use of trade, firm, or corporation names in this publication is for the information and convenience of the reader. Such use does not constitute an official endorsement or approval by the U.S. Department of Agriculture of any product or service to the exclusion of others which may be suitable. 


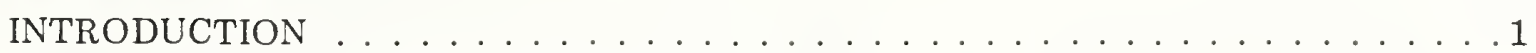

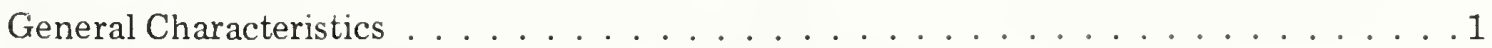

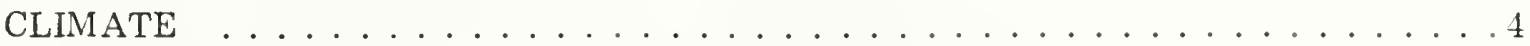

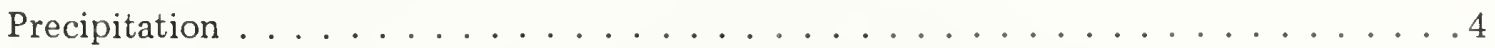

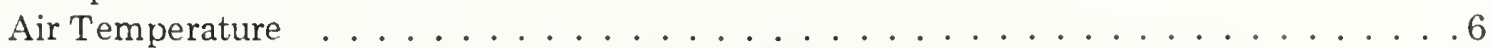

Additional Climatic Measurements . . . . . . . . . . . . . . . . 6

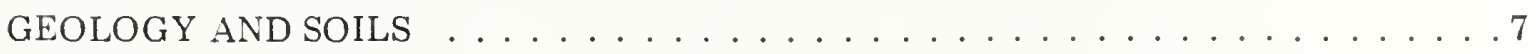

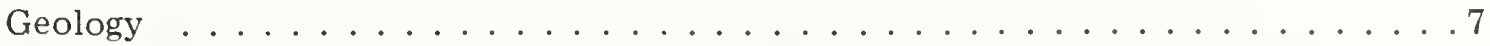

Seismic Survey . . . . . . . . . . . . . . . . . . . . . . . 7

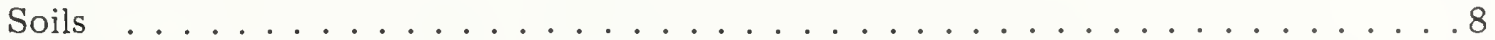

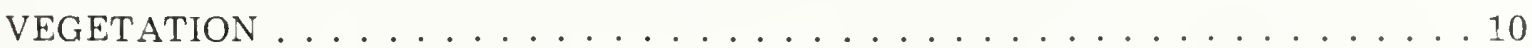

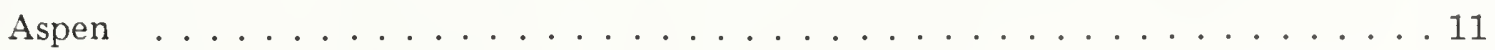

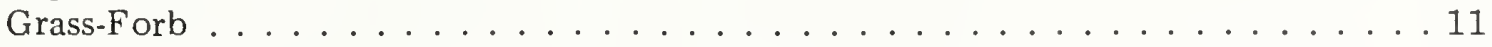

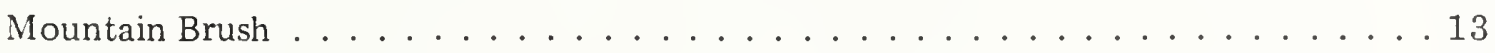

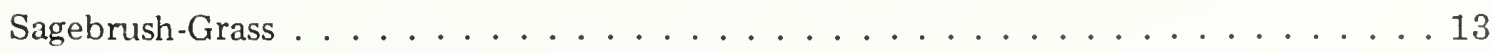

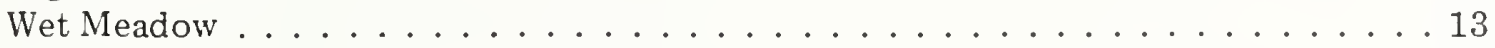

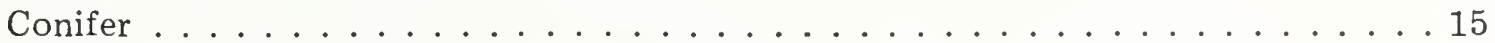

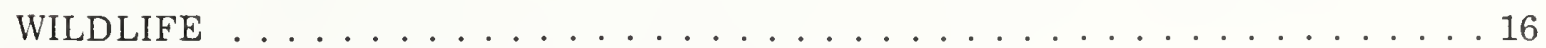

SOIL MOISTURE AND EVAPOTR ANSPIRATION . . . . . . . . . . . . 17

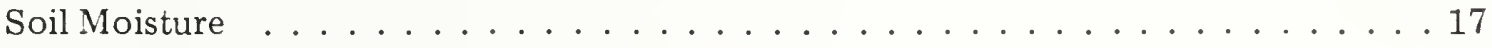

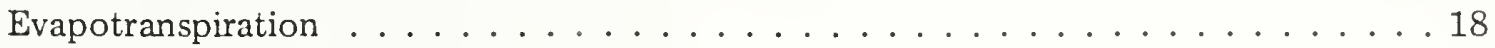

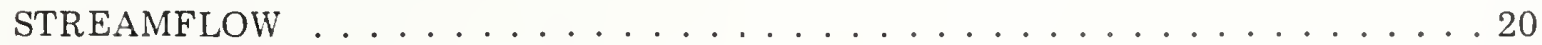

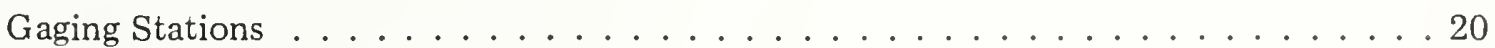

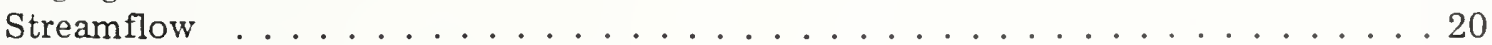

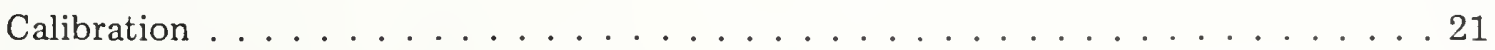

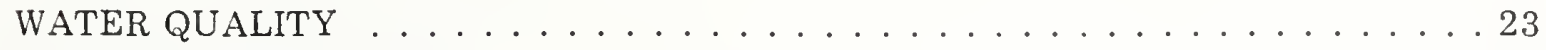

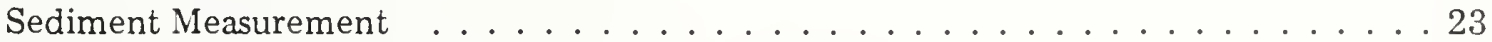

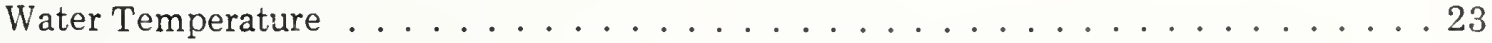

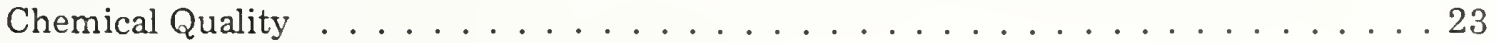

Bacteriological Quality . . . . . . . . . . . . . . . . . 24

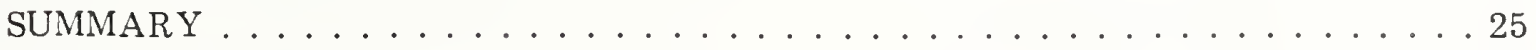

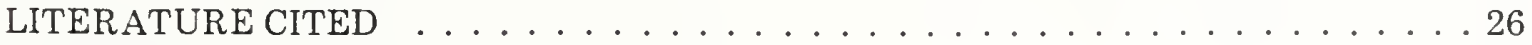

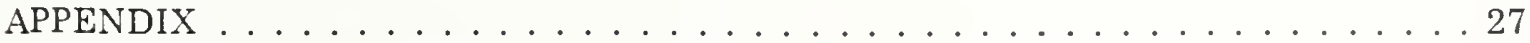

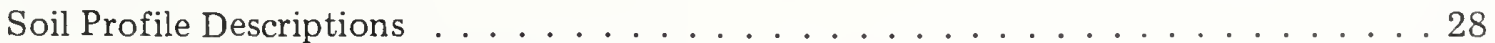

Laboratory Analysis of Soils (Table 7) . . . . . . . . . . . . . . 40-41

Streamflow Summary $($ Table 8$) \ldots \ldots \ldots \ldots$. . . . . . . . . . . . . . . . . . . . . . . . . . . . . . . . .

Common and Scientific Names of Species . . . . . . . . . . . . . . . 43

Water Quality Analysis (Table 9) . . . . . . . . . . . . . . . . . . . . . . . . . . . . . .

Water Quality Analysis (Table 10) . . . . . . . . . . . . . . . . 46

Isopach Map of the Depth of Surface Material . . . . . . . . . . . . . . . 48

Map of the Velocity of the Second Layer . . . . . . . . . . . . . . . . . 49

Soil Classification Map . . . . . . . . . . . . . . . . . . . 52

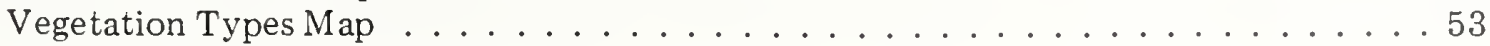




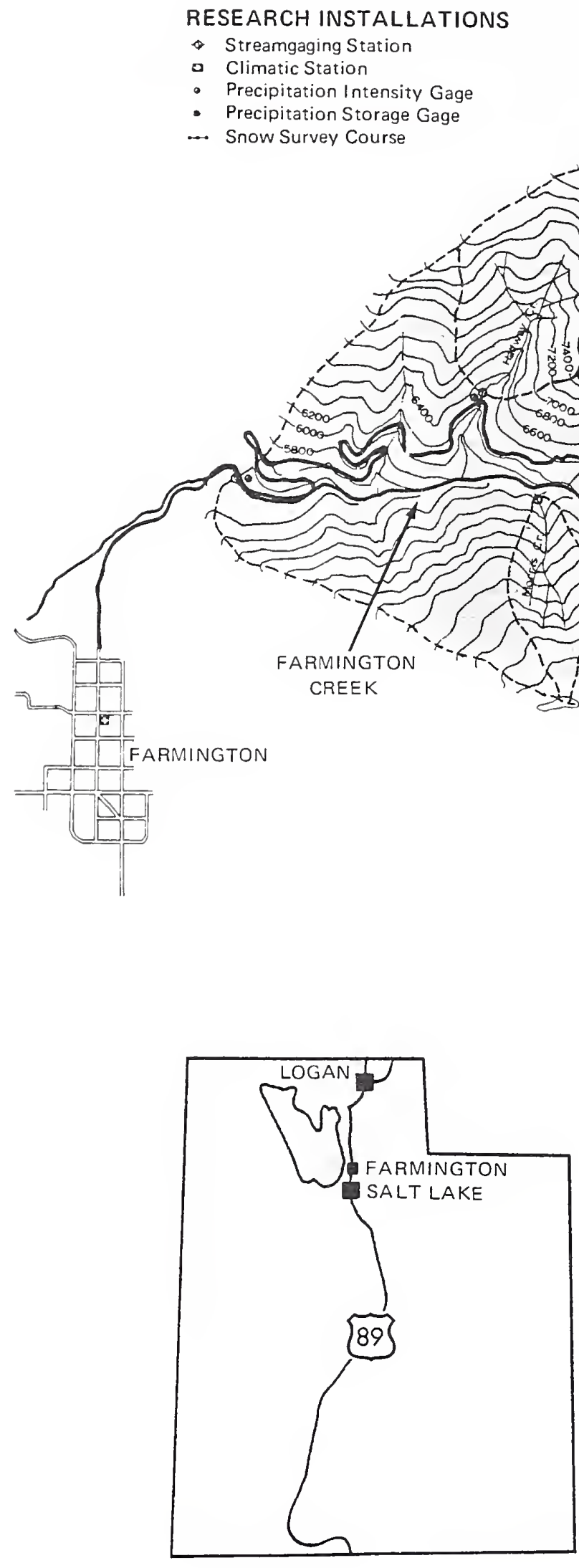

- Strearngaging Station

- Climatic Station

- Precipitation Intensity Gage

- Precipitation Storage Gage

... Snow Survey Course

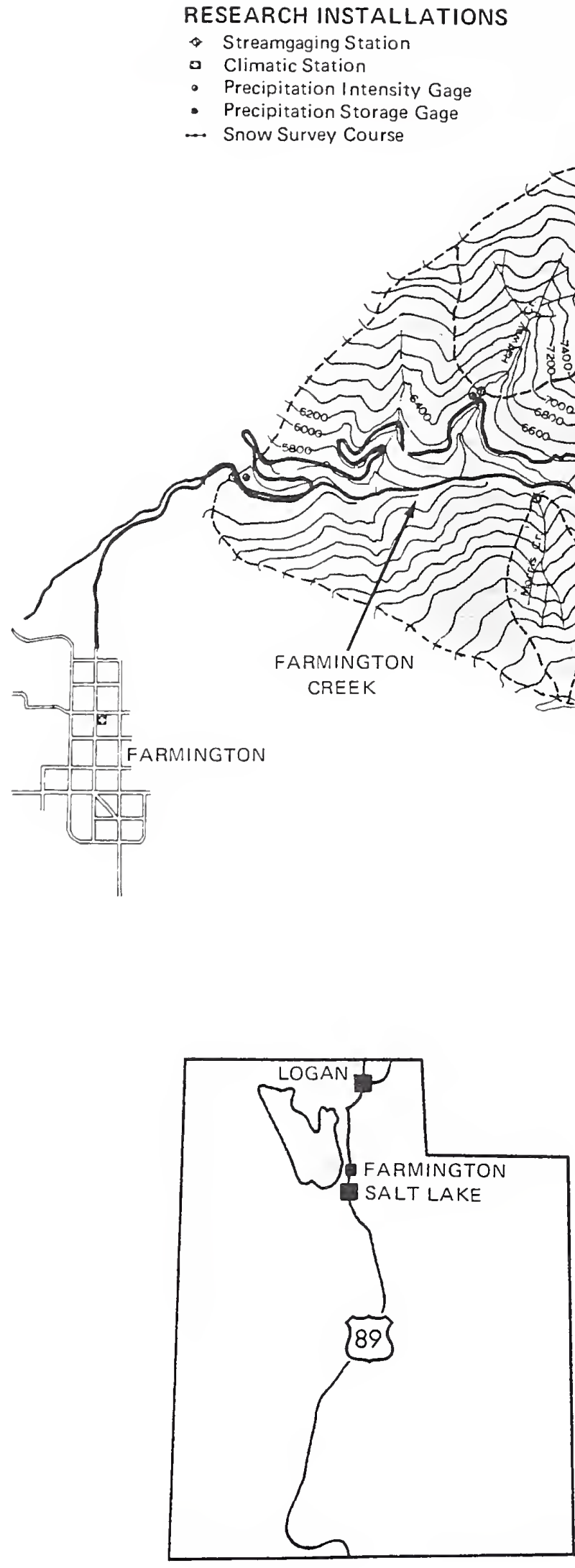

\author{
西
}

(1)

BOUNTIFUL PEAK 9259'

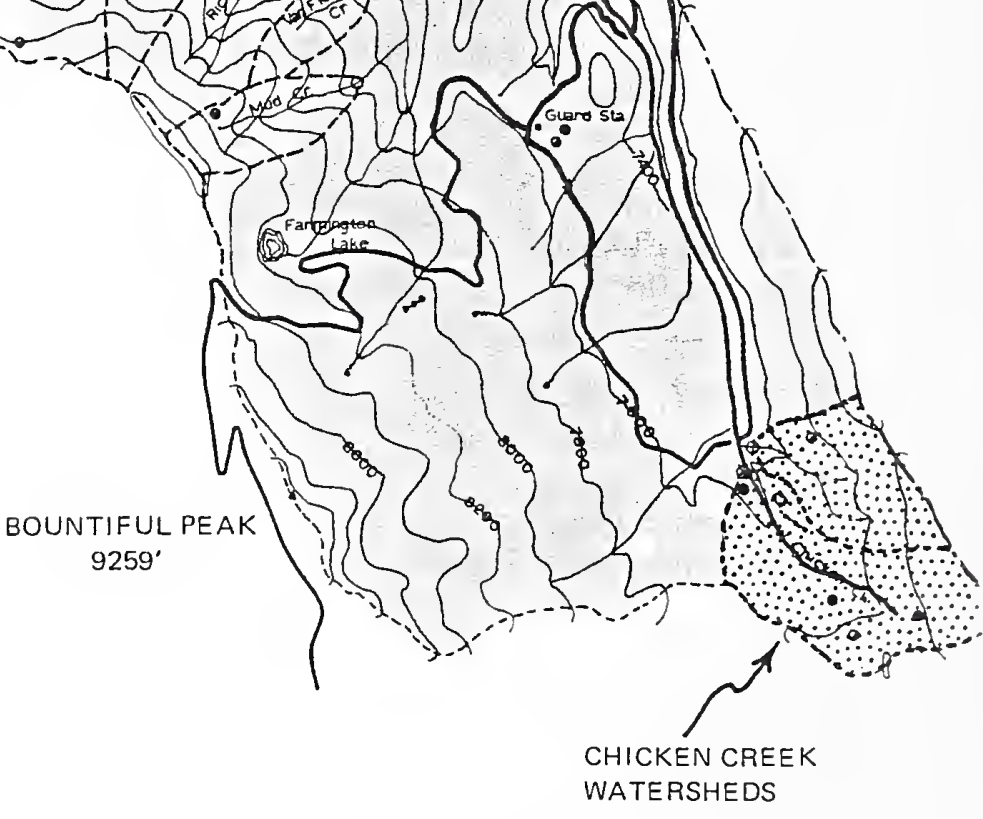

Figure 1. - The Farmington Canyon drainage and Chicken Creek watersheds. 
The Davis County Experimental Watershed (DCEW) was established in 1930 as a USDA Forest Service administered research area, dedicated to the study of the causes and prevention of erosion and floods originating from mountain watersheds. The area consists of 18,000 acres of mountain lands, ranging in elevation from 4,500 to 9,200 feet in the Wasatch Range of north-central Utah. More recently, considerable research has been devoted to the evaluation of vegetation influences on water yields (Croft and Monninger 1953; Tew 1969; Johnston and others 1969; Johnston 1970). These studies have shown that substantial reductions in soil water loss can be realized, if tree and brush species are removed from the sites that have deep soils. The scope of these studies has been restricted to small plots. Logical succession dictates that these results be tested on larger areas, such as entire watersheds, to provide a better evaluation of treatments in terms of actual management conditions.

The two watersheds described in this paper, the East Branch and West Branch of Chicken Creek, are located in the headwaters of Farmington Canyon (fig. 1). These two watersheds have been completely protected from both fire and livestock grazing for nearly 40 years. Initial study of the hydrologic response of the watersheds began in 1952 and continued intermittently until the present. Streamflow was measured on both watersheds from 1952 to 1958 using 90 "V" notch weirs. Measurements of air temperature and precipitation were taken from 1956 to 1959. In 1962 a U.S. Weather Bureau class "A" pan evaporation station was installed on each watershed as part of a cooperative study of evaporation rates in mountainous terrain (Peck and Pfankuch 1964; Peck 1967). Although discontinuous, these past records provided valuable data for the present hydrologic inventory.
In 1965, " $H$ " type flumes equipped with heating devices were installed near the mouth of each watershed (Doty and Johnston 1967). A network of precipitation gages was established and soil moisture measurements were begun on plots in the meadow, under mature aspen, and on areas clearcut of aspen, using neutron measuring techniques. In succeeding years, seismic, soil, and vegetation inventories were completed.

This report summarizes the data collected during the pretreatment hydrologic inventory of these watersheds. The information will be used to prescribe a vegetation treatment and to designate the areas to be treated to increase water yield; the primary considerations are to preserve water quality and obtain a high degree of protection against erosion. The data will also provide a measure for evaluating the changes that occur as a result of treatment. Finally, the report furnishes the most complete description available of a natural catchment in the Wasatch Mountains and thus serves as valuable reference material for land managers.

\section{General Characteristics}

The East and West Branches of Chicken Creek are small, adjacent watersheds (137 and 217 acres, respectively). They generally have northwest aspects, and lie within the 7,500. to 8,400 -foot elevation zone (table 1 and fig. 2).

The side slopes of both watersheds are relatively gentle and have gradients ranging from 12 to 45 percent. A gently sloping meadow occupies the bottom of each drainage and a comparatively subdued ridge forms the boundary between the two drainages. These landforms are considered to be relatively "old surfaces" according to recent geologic papers (Bell 1952). 


\section{LEGEND:}

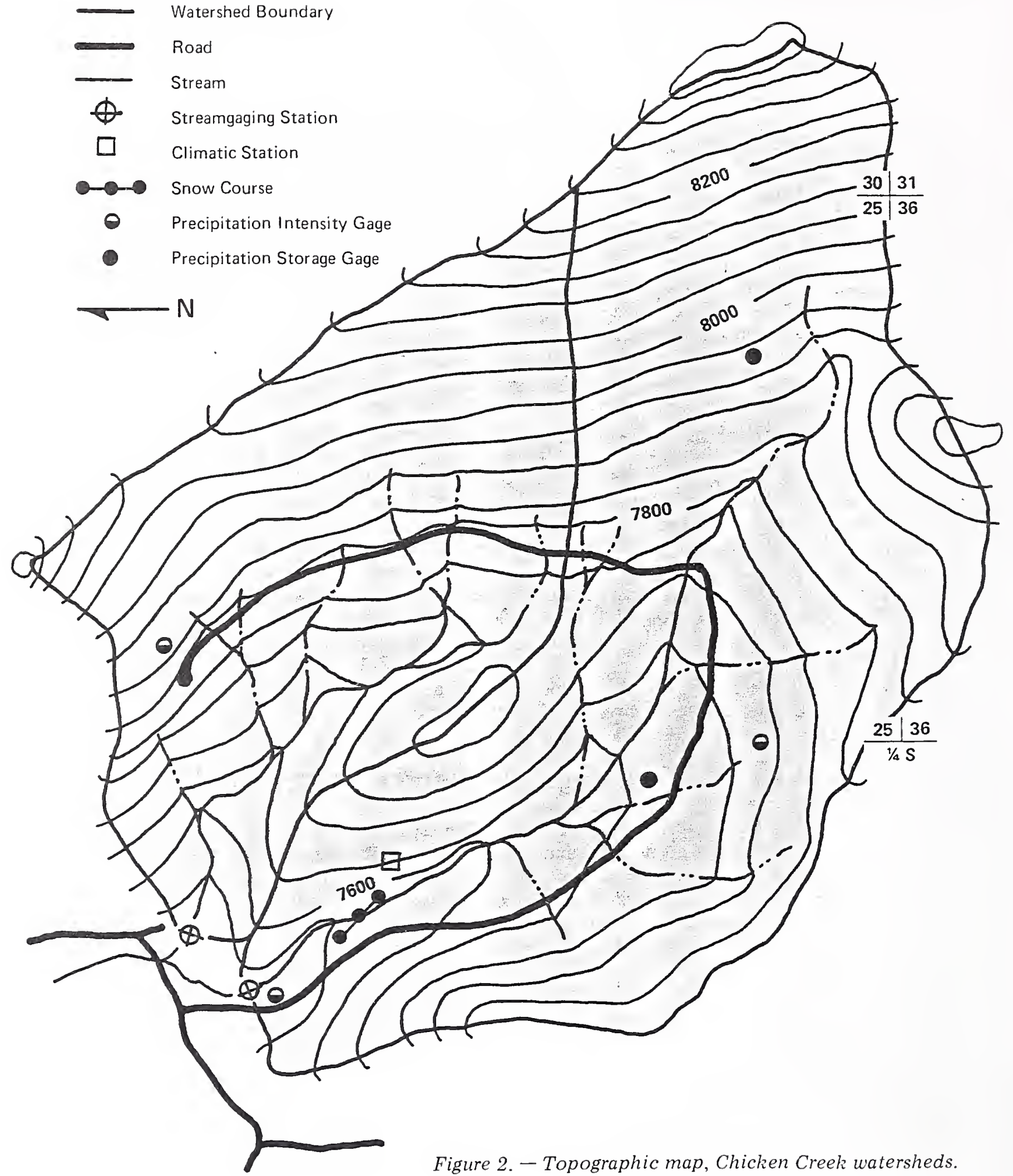

Figure 2. - Topographic map, Chicken Creek watersheds. 
Table 1. - Characteristics of the Chicken Creek watersheds ${ }^{1}$

\begin{tabular}{|c|c|c|}
\hline Unit of Measure & $\begin{array}{l}\text { East } \\
\text { Branch }\end{array}$ & $\begin{array}{l}\text { West } \\
\text { Branch }\end{array}$ \\
\hline $\begin{array}{c}\text { Area } \ldots \ldots \ldots \ldots \text { Acres } \\
\ldots \ldots \ldots \ldots \text { Square miles }\end{array}$ & $\begin{array}{r}137 \\
0.214\end{array}$ & $\begin{array}{l}217 \\
0.341\end{array}$ \\
\hline $\begin{array}{l}\text { Elevation } \\
\quad \text { Minimum ....... Feet } \\
\quad \text { Maximum ...... Feet }\end{array}$ & $\begin{array}{l}7,540 \\
8,240\end{array}$ & $\begin{array}{l}7,550 \\
8,396\end{array}$ \\
\hline Aspect & NW & NW \\
\hline Slope . . . . . . . . . Average percent & 24.0 & 19.5 \\
\hline $\begin{array}{l}\text { Stream channel } \\
\text { Length . . . . . . . Feet } \\
\text { Elevation range..... Feet } \\
\text { Density . . . . . . . . Miles per square mile }\end{array}$ & $\begin{array}{l}2,494 \\
200 \\
2.19\end{array}$ & $\begin{array}{r}4,209 \\
300 \\
2.34\end{array}$ \\
\hline
\end{tabular}

${ }^{1}$ The drainage system of both watersheds consists of a single well-defined main channel, with several, generally poorly developed, side branches that furnish only intermittent flows. 
The climate of the two watersheds comprising the study area is generally representative of large areas of midelevation $(7,000-8,000 \mathrm{ft}$.) mountain country in the Intermountain region. Winter weather patterns are primarily influenced by frontal systems moving in from the Pacific Northwest. For 6 months of the year (NovemberApril), winter prevails, and average monthly temperatures are uniformly below 30 degrees; however, periods of subzero temperatures are both infrequent and of short duration. Heavy snowfall accounts for about 80 percent of the yearly precipitation. Summers are short, cool, and dry. Most summer storms are convective thunderstorms, although a few are associated with weak fronts moving eastward from the Pacific. Prevailing winds are from the south and southwest carrying summer moisture aloft from the Gulf of Mexico.

As in most of the Intermountain region, aspect greatly influences the study area's climate by affecting radiation, temperature, wind, and moisture regimes. Response to these influences is markedly reflected in the local vegetation patterns.

A climatic station was established on the West Branch watershed (fig. 2) in May 1971. Total and net radiation, air temperature, relative humidity, wind direction, and windspeed at two elevations are being continuously recorded.

\section{Precipitation}

The precipitation network on the two study watersheds consists of one recording intensity gage, three storage gages, and two additional intensity gages used only during the summer months. Storage gages have been in use since 1956 , except for the years
1960-1962. Summer intensity records are available for 1962 and from 1964 and thereafter. The network is supplemented by long-term (up to 30 years) summer intensity records from 14 nearby stations at elevations ranging from 4,350 to 9,000 feet on the DCEW and from two additional storage gages at 6,800 and 7,500 feet elevation in the Farmington Creek drainage where the study watersheds are located.

Average yearly precipitation on the study watersheds is 45 inches, and, as noted earlier, 80 percent of this occurs as snow. The monthly distribution of precipitation is presented in figure 3 . The June-through-September period is the driest of the year, and a 9-year average for this period was only 5.06 inches. However, summer rainfall is quite variable, ranging from 1.01 to 12.82 inches per year. Converse-

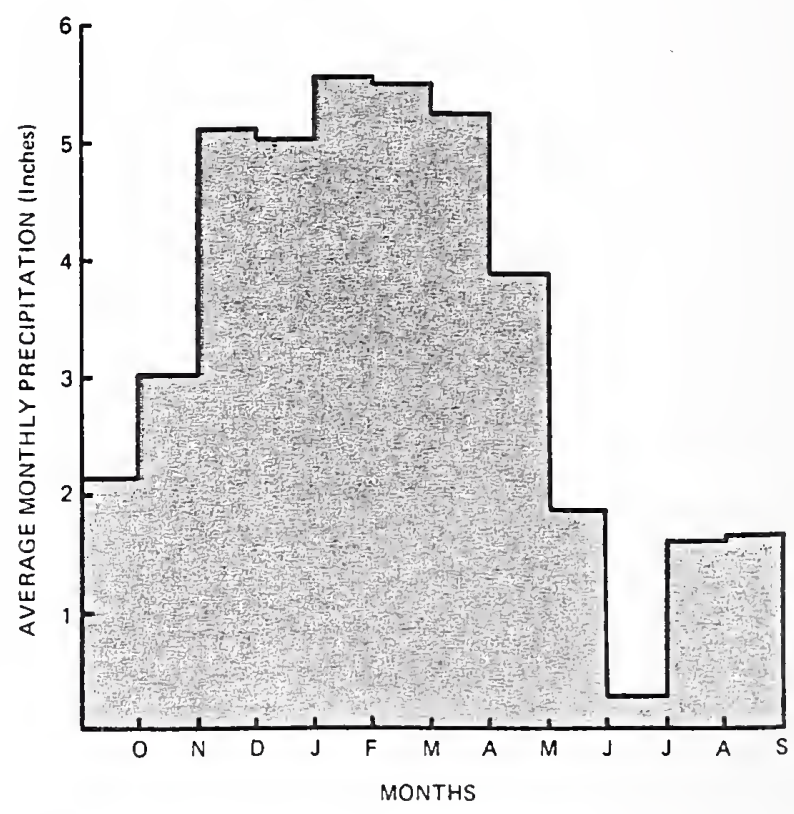

Figure 3. - Distribution of average monthly precipitation, 1956-1959. 
ly, winter precipitation is very uniform; the average precipitation varies only one-half inch per month during the December-throughApril period.

Farmer and Fletcher (1971) completed a detailed analysis of all intensity gage records obtained from DCEW through 1968; at some stations, this included up to 30 years of records. These records gave evidence that most summer storms are of less than 6 hours duration and that intensity generally decreases with elevation. Also, the records revealed that total rainfall at DCEW is generally highest in the upper reaches of Farmington Canyon from about 6,000 to 8,000 feet elevation, which includes our study watersheds, the East Branch and West Branch of Chicken Creek. Figure 4 shows the probable recurrence interval for various storm intensities that range 2 minutes to 6 hours in duration (Farmer and Fletcher 1971). For example, a storm having a maximum 5-minute intensity of 3.7 inches per hour has a probable recurrence interval of 10 years; a storm having a maximum 5 -minute intensity of 6 inches per hour has a recurrence interval of 50 years.

During the entire period of record on our study watersheds, the maximum 5-minute intensity recorded was 2.04 inches per hour.

A snow course has been maintained at 7,600 feet elevation on the West Branch watershed since 1967. During the period of record, the average snow depth for April 1 was 53.3 inches and the average water content for that same date was 18.6 inches. Two additional snow courses, Lower and Upper Farmington Canyon, have been maintained in cooperation with the Soil Conservation Service since

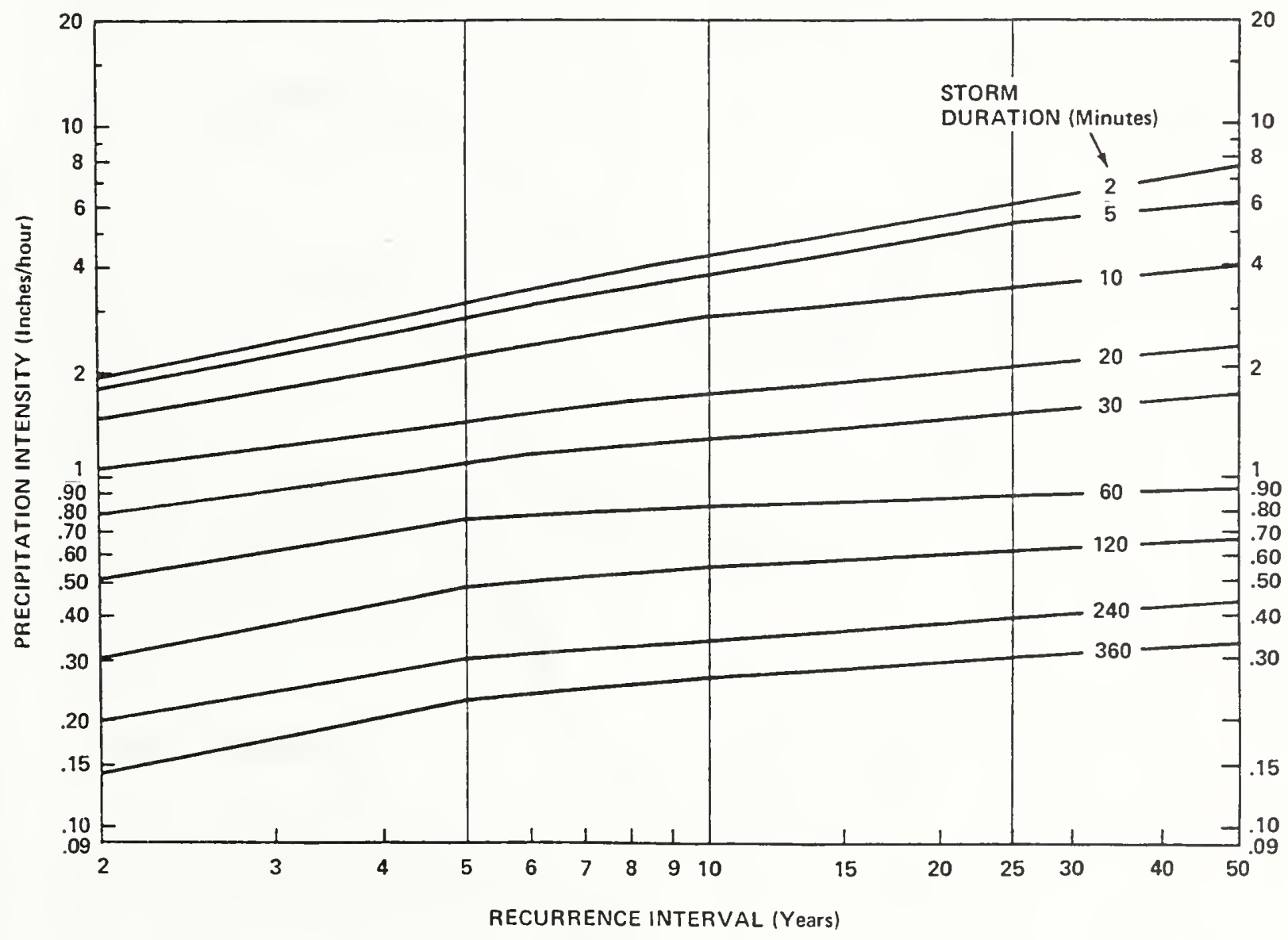

Figure 4. - Recurrence intervals of summer storms of various intensities and durations ranging from 2 to 360 minutes. Curves are representative of that precipitation zone which includes the upper Farmington Creek drainage. 
1951 at elevations of 6,950 and 8,000 feet. The 18-year average for April 1 water content at these snow courses is 23 and 28 inches, respectively.

\section{Air Temperature}

Temperature records on the two study watersheds were maintained from 1956 to 1959 and during the summer of 1962 . Winter records were sporadic, but missing records were estimated by using the equation ( $\mathrm{Y}=1.059 \mathrm{X}$ 4.279 , with $\mathrm{R}^{2}=0.96$ ) derived from the excellent 32-year record at Rice Climatic Station, located at 6,900 feet elevation in Farmington Canyon.

The mean annual temperature at Chicken Creek was a cool $36.6^{\circ} \mathrm{F}$., and extreme temperatures ranged from $-20^{\circ}$ to $88^{\circ} \mathrm{F}$. Periods of subzero temperatures were infrequent and usually brief. The mean July-through-September temperatures were consistently in the upper 50's, and mean November-through-April temperatures varied from $20^{\circ}$ to $25^{\circ} \mathrm{F}$. (fig. 5 ). Below freezing temperatures have occurred in every month of the year at some time during the period of record.

\section{Additional Climatic Measurements}

A climatic station was established on the West Branch watershed in June 1971. Parameters being recorded are: total and net radiation; windspeed at two elevations; wind direction; air temperature; and relative humidity. These data will be used to determine energy budget and potential evapotranspiration relations for the area.

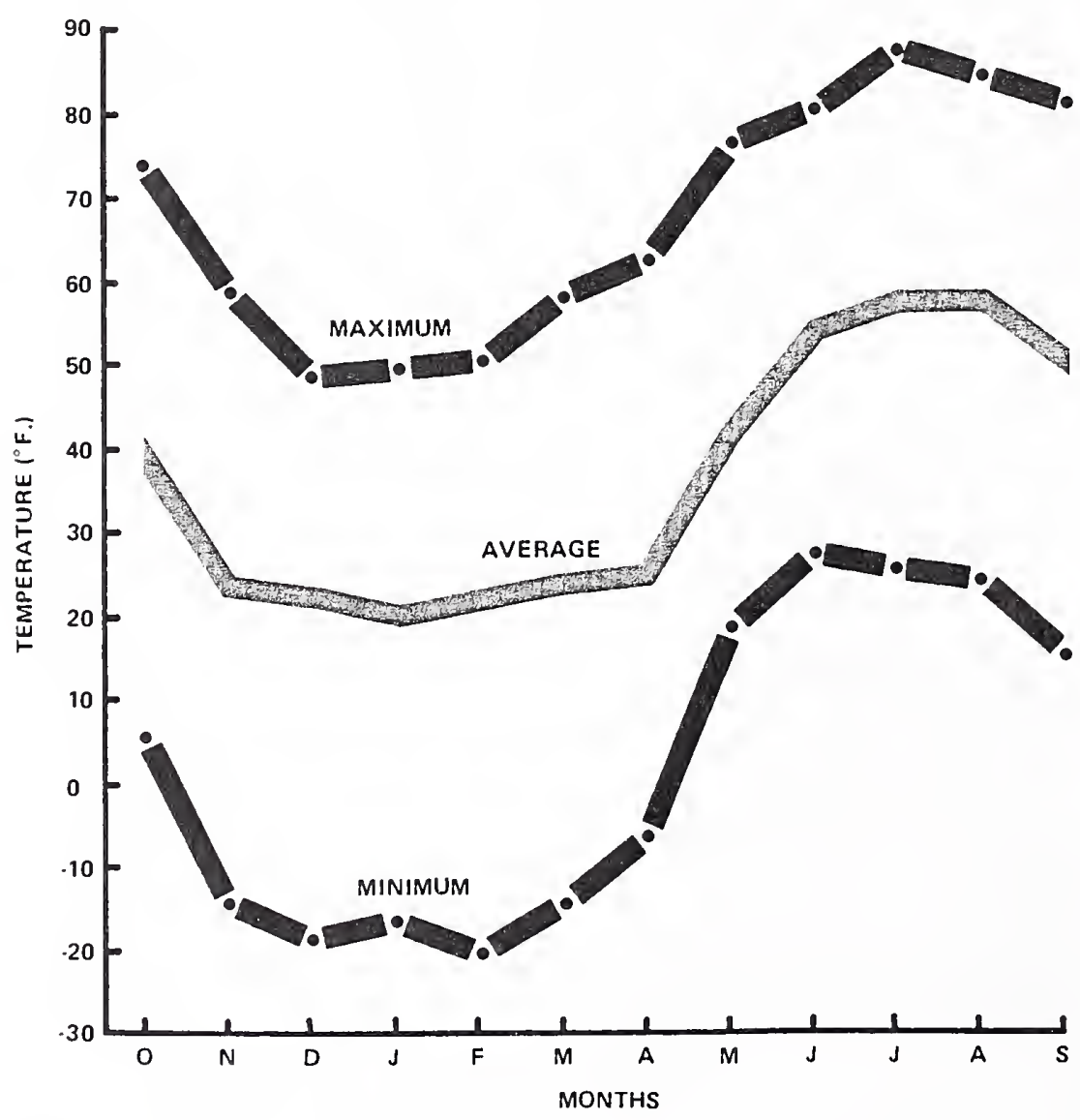

Figure 5. - Mean monthly temperature and observed maximum and minimum temperatures for the periods 1956-1959 and 1962. 


\section{Geology}

Geologically, the Wasatch Mountains east of Farmington are very complex; they show evidence of folding, major and minor faulting, uplift, and multiple erosion cycles. Bell (1952) describes the area as "... essentially a composite series of north-northwest trending fault blocks bounded by normal faults." The two study watersheds lie between the Wasatch Fault's main crest (which overlooks Great Salt Lake) and a subsidiary crest which forms the northeastern boundary of these watersheds.

The underlying bedrock is a complex series of igneous, metamorphic, and sedimentary rocks. Scattered remnants of a coarse tertiary conglomerate (Knight formation) occur in the lower portions of the area and also to the west of the watershed boundary. These rocks consist of a series of interbedded, reddishcolored shales, siltstones, sandstones, and conglomerates. The most prevalent rock types are metamorphic gneiss and schistose families intruded by relatively narrow bands of pegmatites. Migmatites (composite gneiss) and greenstone schists are also abundant. Finally, outcroppings of Pre-Cambrian quartz are apparent on the ridge crests. Some of the more common mineral constituents include: feldspars (dominantly plagioclase), quartz, muscovite, chlorite, biotite, epidote, and actinolite.

\section{Seismic Survey}

A shallow-depth seismic survey was completed for the study areas using an MD-3 seismograph (Soiltest, Inc.). The survey consisted of 226 systematically located transects, each 120 to 150 feet in length, which provided subsurface information to a depth of 40 to 50 feet.
Careful correlation of the seismic data with the information obtained from test holes and other known surface and subsurface characteristics provides a wealth of geologic and hydrologic information such as: thickness and depth of subsurface layers, hardness, weathering, stratification, fracturing, faulting, and dip angle of strata.

An isopach map of subsurface depths (page 48) was prepared to aid in planning a watershed treatment that would offer the greatest potential for increasing water yields. This map indicates the depth of low velocity (700 to 1,600 feet per second (f.p.s.), loosely consolidated surface material. This surface layer is generally quite deep on both watersheds, with only small scattered areas less than 5 feet deep in the West Branch.

The isopach map indicates that the depth of the low-velocity, surface-soil layer along the eastern ridge ranges from 5 to 10 feet and occasionally down to 15 feet in the saddles. In this case, information from the surface soils is lost because of their very shallow depths and the very similar velocities of the soil material and the dry, strongly weathered and fractured underlying gneiss. From the standpoint of water movement and storage, this soil-rock complex may be considered quite deep.

It was not possible to calculate second layer soil depths for more than a quarter of the transect lines; thus, there are probably too few depths to plot an accurate isopach map of the second layer. A plot of equal velocity lines and available depth information is shown on page 49 . With few exceptions, the second layer is greater than 20 feet deep and is composed of fairly low velocity material in the 3,000 to 5,000 f.p.s. range. This layer is either wet or compacted alluvial material in the valley bottoms or it is deeply weathered gneiss and schistose parent material on the ridges 
and side slopes. We can assume that second layer depths exceed 40 feet where the depth is not indicated. Several "ridges" of high velocity ( 8,000 to 9,000 f.p.s.), unweathered material are present along the bottoms of both watersheds. The velocity of the third layer ranged from 9,000 to 20,000 f.p.s., indicating consolidated granitic and unweathered gneiss.

\section{Soils}

Soils on the two study watersheds were described and mapped in a medium intensity survey which defined 11 soil mapping units shown on page 52. No attempt was made to place soils in established series. Soil profile descriptions are presented in the Appendix, and laboratory analysis of the soils is presented in table 7 of the Appendix.

A wide variety of soils is found on the two study watersheds. They range from very deep loamy alluvial soils in the valley bottoms (unit 16) to very deep clayey soils in colluvium on side slopes (unit 13) and shallow gravelly loam on the ridges (unit 10). Soils developing from the metamorphic rocks range from medium texture to moderately fine texture, while those developing from sedimentary material range from moderately fine texture to fine texture. Generally, the soils are deep and have good moisture-holding capacities, except on the ridges.

Soil units 12 and 13 comprise nearly 55 percent of the soils on both watersheds (table 2 ). These soils are very deep loamy and very deep clayey soils, respectively, developed in colluvium on the side slopes. Soil unit 21 comprises 15 percent of the total area, but occurs mostly in the West Branch. This is a very deep loamy soil found on the side slopes in the lower part of the watershed, but differs from unit 12 in that the parent material is siltstone and shale instead of the mixed metamorphic parent material of unit 12 . Soil unit 16 , the fourth largest, is a very deep loam developing on alluvial material in the bottom of both drainages.

The descriptive depths refer to the pedological development and do not necessarily reflect the hydrologic behavior or water-holding characteristics of the area. The ridge soils

Table 2. - A comparison of the size and occurrence of the various soil mapping units on the Chicken Creek Watersheds

\begin{tabular}{lrrr}
\hline & & \multicolumn{2}{c}{$\begin{array}{c}\text { Percent of watershed areas } \\
\text { exhibiting each soil unit }\end{array}$} \\
Soil unit & $\begin{array}{c}\text { Total size } \\
\text { (both watersheds) }\end{array}$ & East Branch & West Branch \\
\hline & Acres & & 3.2 \\
11 & 16.15 & 6.7 & 6.1 \\
12 & 31.93 & 13.6 & 26.5 \\
13 & 113.12 & 40.4 & 24.3 \\
14 & 80.78 & 20.3 & 2.2 \\
16 & 9.32 & 3.3 & 10.8 \\
18 & 33.68 & 7.4 & 2.2 \\
19 & 4.80 & -- & 1.2 \\
20 & 2.62 & -- & 4.1 \\
21 & 8.93 & -- & 18.4 \\
22 & 51.48 & 8.3 & 1.0 \\
\hline
\end{tabular}


(unit 10) are shallow, but the water-holding capacity of that zone is quite high because of a deep zone of fractured and weathered parent material.

All soils were considered well-drained except units 16 and 18, which were classified as moderate to imperfectly drained and poorly drained, respectively. Most soils were rated " $\mathrm{C}$ " in the hydrologic soil group classification
(Soil Conservation Service) which is described as ranging from silty to silty clay loam having restricted permeability. Only the ridge soils (unit 10) were rated "A," fairly light soils offering minimum restriction to downward water movement, while the poorly drained soils in unit 18 were rated "D." All soils were judged to have a moderate inherent erosion hazard. 


\section{VEGETATION}

The early history (1847 to 1930) of land use along the Wasatch Front is marked by logging, fire, and severe overgrazing. Timber stands were depleted, regeneration was suppressed, and meadow and understory grasses and forbs were depleted (fig. 6). Mud-rock floods originated on denuded mountain slopes and meadows during high intensity summer rainstorms. Since its inclusion in the National Forest System in 1933, the DCEW has been completely protected from logging, fire, and grazing by domestic livestock. In addition, in- tensive watershed restoration practices, including contour furrowing and reseeding, were applied to flood-source areas which included the stream bottoms and lower side slopes of both study watersheds of Chicken Creek. The areas that were contour furrowed are generally defined on the soils map (page 52 ) by soil type 16 and some of the adjacent areas; the furrowed areas comprised about 15 percent of both watersheds. Most of the treated area remains in grass and brush vegetation, but some furrows can be seen in the low-

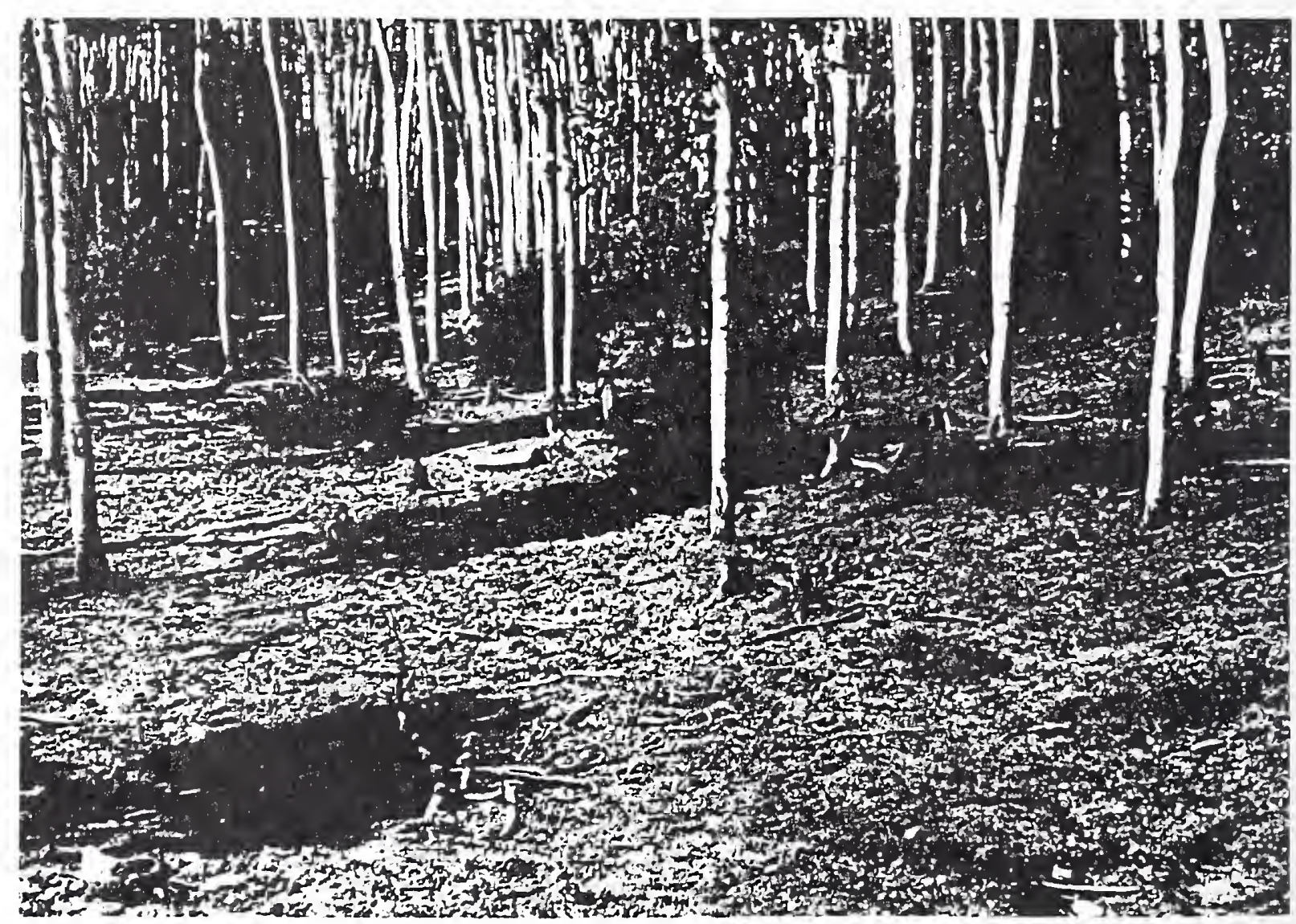

Figure 6. - An aspen stand that has been logged and heavily grazed. Forage is depleted, aspen regeneration is suppressed, and the exposed soil presents a serious erosion hazard. Photographed during the era of severe land abuse, circa 1930. 
er aspen clones which suggests that these clones expanded following treatment. Today, understory vegetation and litter cover 54 to 90 percent of the ground and natural reproduction has largely stocked the forest.

Twenty-eight specific vegetation types were delineated in the original survey. These have been broadly grouped into seven major classifications (page 53). It should be recognized that many variations in both species and composition exist within these broad groups. For example, the grass-forb type along the ridge is quite different from that along the stream bottom. Aspen, and the lush understory of grasses and forbs, covers more than 60 percent of both watersheds (table 3 ). Near the ridgetops, aspen gives way to a sagebrushgrass type and finally to a narrow band of grasses and forbs near the crests. A second band of the grass-forb type generally follows the stream bottoms of the two watersheds, changing occasionally to a wet-meadow type. Small areas of mountain brush (snowberry, chokecherry, and serviceberry $)^{l}$ are scattered throughout the watersheds, each of which has one small area of conifers (Douglas-fir and subalpine fir).

'The common and scientific names of all species identified on the watersheds are listed on pages 43 and 44.
Timber stands on the study area have little or no commercial value because of their generally poor form and a lack of a suitable market.

\section{Aspen}

The aspen type (fig. 7) occupies more than 60 percent of each of the two watersheds and is found throughout except along the stream bottoms and the ridgetops. The aspen generally have poor form and show a fairly high incidence of canker and heart rot, although these characteristics vary considerably between clones. Average age of the aspen is 32 years although a few individual trees are in the 70- to 80-year-old class. Average diameter (d.b.h.) is 4.2 inches and the average height is 23 feet. Basal area varies from 20 to 140 square feet per acre and the average is 82 . A lush understory of forbs and grasses is characteristic of these aspen stands. Some of the more prevalent associated species are: California brome; western wheatgrass, rye grass, bluebell, sweetpea, and false hellebore.

\section{Grass-Forb}

The grass-forb type (fig. 8) occupies 12 to 13 percent of each of the two watersheds and

Table 3. - Vegetation types of the Chicken Creek watersheds. A comparison of their extent on each watershed and ground cover conditions on both watersheds

\begin{tabular}{|c|c|c|c|c|c|c|}
\hline \multirow[b]{2}{*}{$\begin{array}{c}\text { Vegetation } \\
\text { type }\end{array}$} & \multicolumn{2}{|c|}{ Percent area } & \multicolumn{4}{|c|}{ Average ground cover on both watersheds } \\
\hline & $\begin{array}{c}\text { East } \\
\text { Branch }\end{array}$ & $\begin{array}{c}\text { West } \\
\text { Branch }\end{array}$ & Vegetation & Litter & Bare & Rock \\
\hline & & & $\ldots \ldots$ & $\cdots P e$ & $\ldots-$ & $\cdots \cdot$ \\
\hline Aspen & 63.1 & 66.0 & 71.2 & 18.7 & 10.1 & 0 \\
\hline Grass-forb & 11.6 & 13.4 & 51.4 & 11.4 & 24.6 & 12.6 \\
\hline Mountain brush & 7.0 & 10.6 & 64.1 & 6.3 & 23.3 & 6.4 \\
\hline Sagebrush & 15.1 & 4.4 & 49.4 & 4.5 & 19.1 & 26.5 \\
\hline Conifer & 2.4 & 3.6 & 48.5 & 34.5 & 16.5 & 0.5 \\
\hline Wet meadow & 0.8 & 2.0 & 82.0 & 9.3 & 8.2 & 0.5 \\
\hline
\end{tabular}




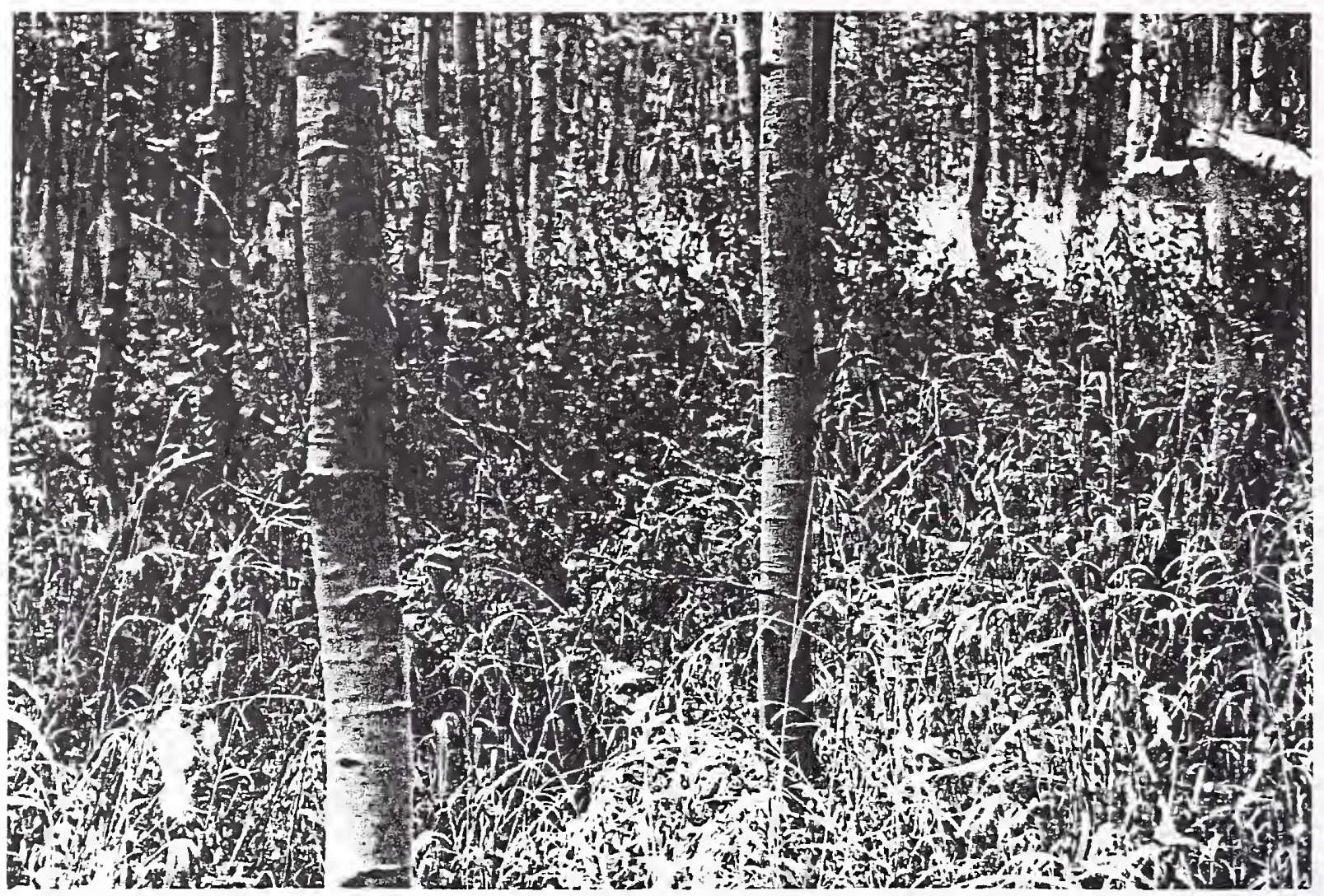

Figure 7. - Aspen community, Chicken Creek watersheds.

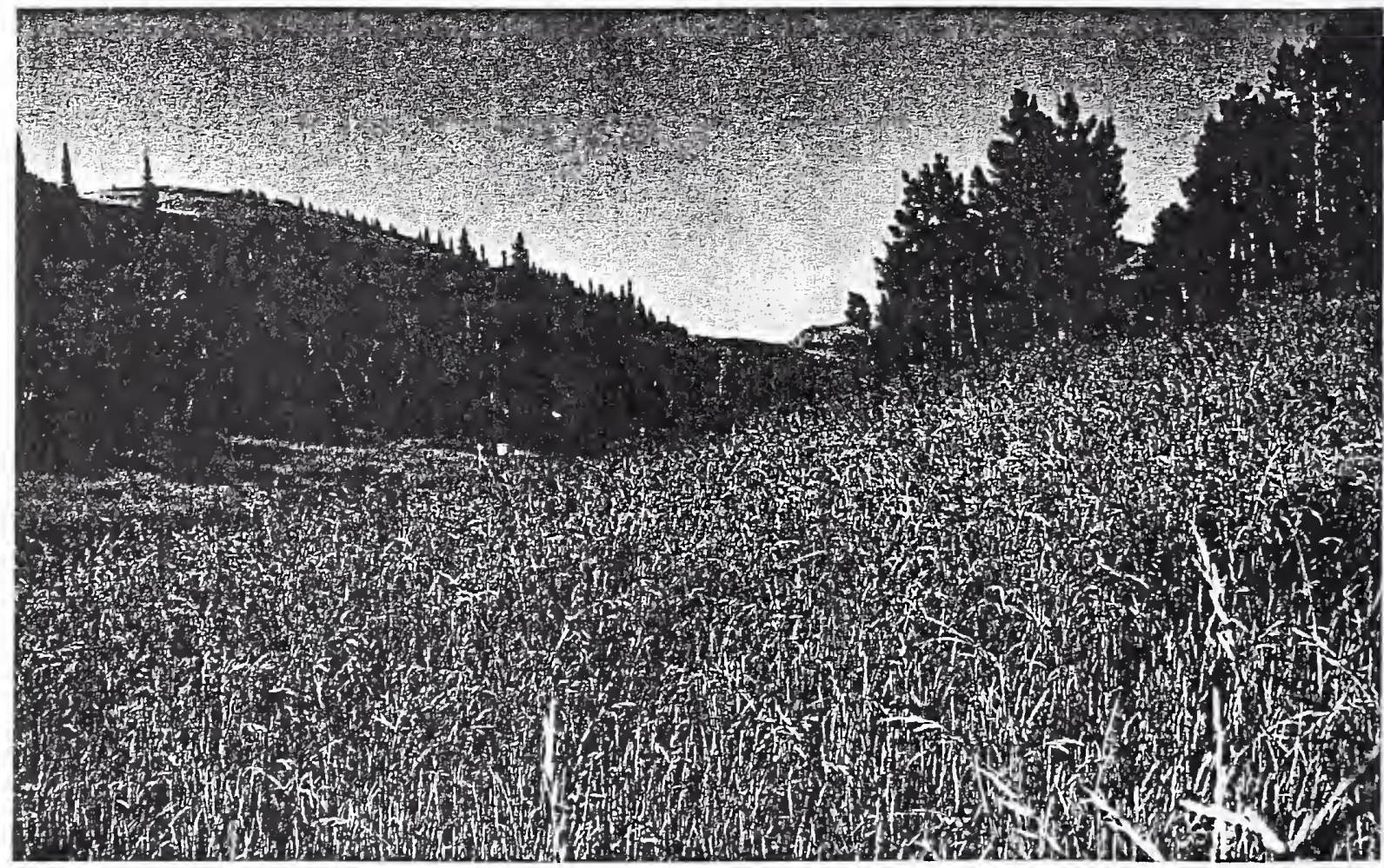

Figure 8. - Grass-forb community, Chicken Creek watersheds. 
occurs mostly along the stream bottoms and along the ridges. Vegetation cover averages 51 percent, but varies from 35 to 73 percent. Up to 44 percent bare ground may be found in some areas. Major species include: California brome, smooth brome, orchard grass, Kentucky bluegrass, June grass, bluebell, sweetpea, goldenrod, aster, lupine, false hellebore, wyethia, tarweed, and catchweed.

\section{Mountain Brush}

Small patches of mountain brush (fig. 9) are scattered throughout both study areas, but the brush is more prevalent on the southwest-facing side slopes above the stream bottoms. This type occupies 7 percent of the East Branch and 11 percent of the West Branch, and the stands are quite dense and difficult to penetrate. Vegetation and litter cover nearly 70 percent of the ground. The major brush species are chokecherry, snowberry, and serviceberry. Other associated species are: tarweed, California brome, pepperweed, bluebell, aster, wyethia, and eriogonum.

\section{Sagebrush-Grass}

The sagebrush type (fig. 10) is largely restricted to a narrow band between the aspen and the ridge line; the sagebrush type occurs on 15 percent of the East Branch but on only 4 percent of the West Branch. Although vegetation covers about 50 percent of the ground on both watersheds, the percent of litter for sagebrush is the lowest of any of the six vegetation types. Sagebrush has a higher percent of rock (25\%) and rock-bare ground combination (45\%) than any other type. Common associates in this type are: snowberry, manzanita, wild rose, rabbitbrush, buckwheat, aster, paintbrush, geranium, lupine, June grass, Caiifornia brome, and Western wheatgrass.

\section{Wet Meadow}

The wet meadow (fig. 11) is a very small but distinctive vegetation type that occupies only 0.8 percent and 2 percent of the East and West Branches, respectively. Where this

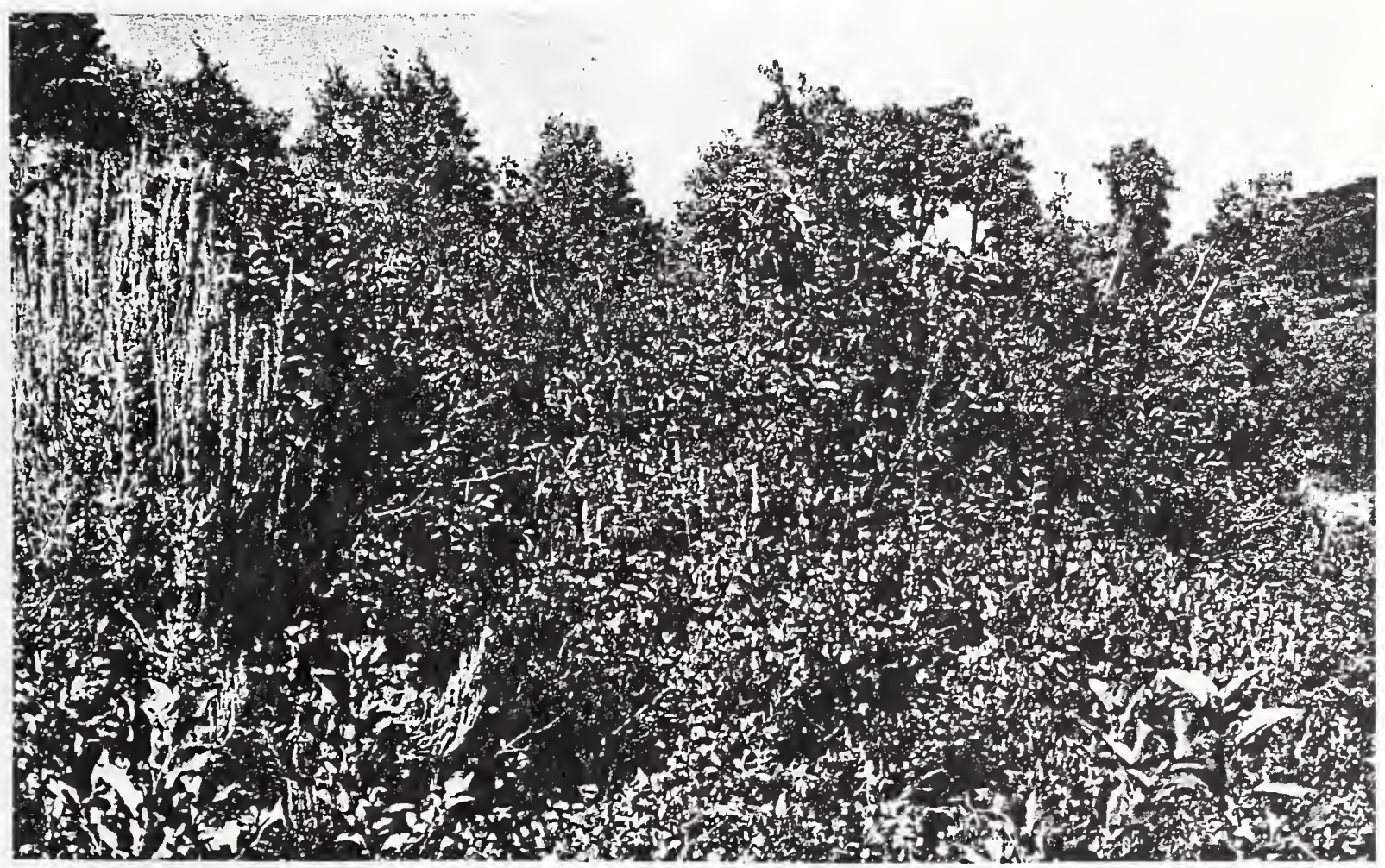

Figure 9. - Mountain brush community, Chicken Creek watersheds. 


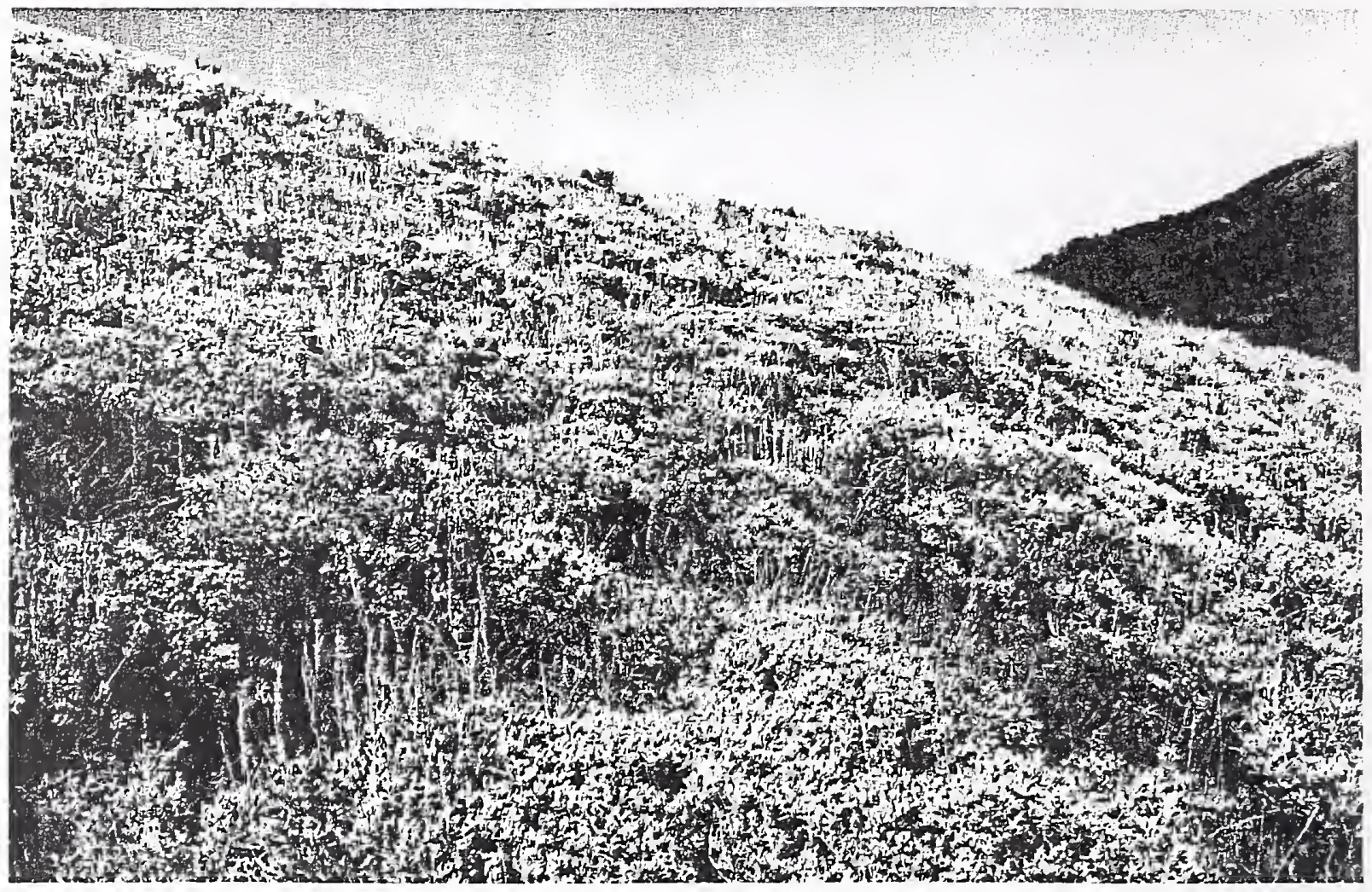

Figure 10. - Sagebrush-grass community, Chicken Creek Watersheds.

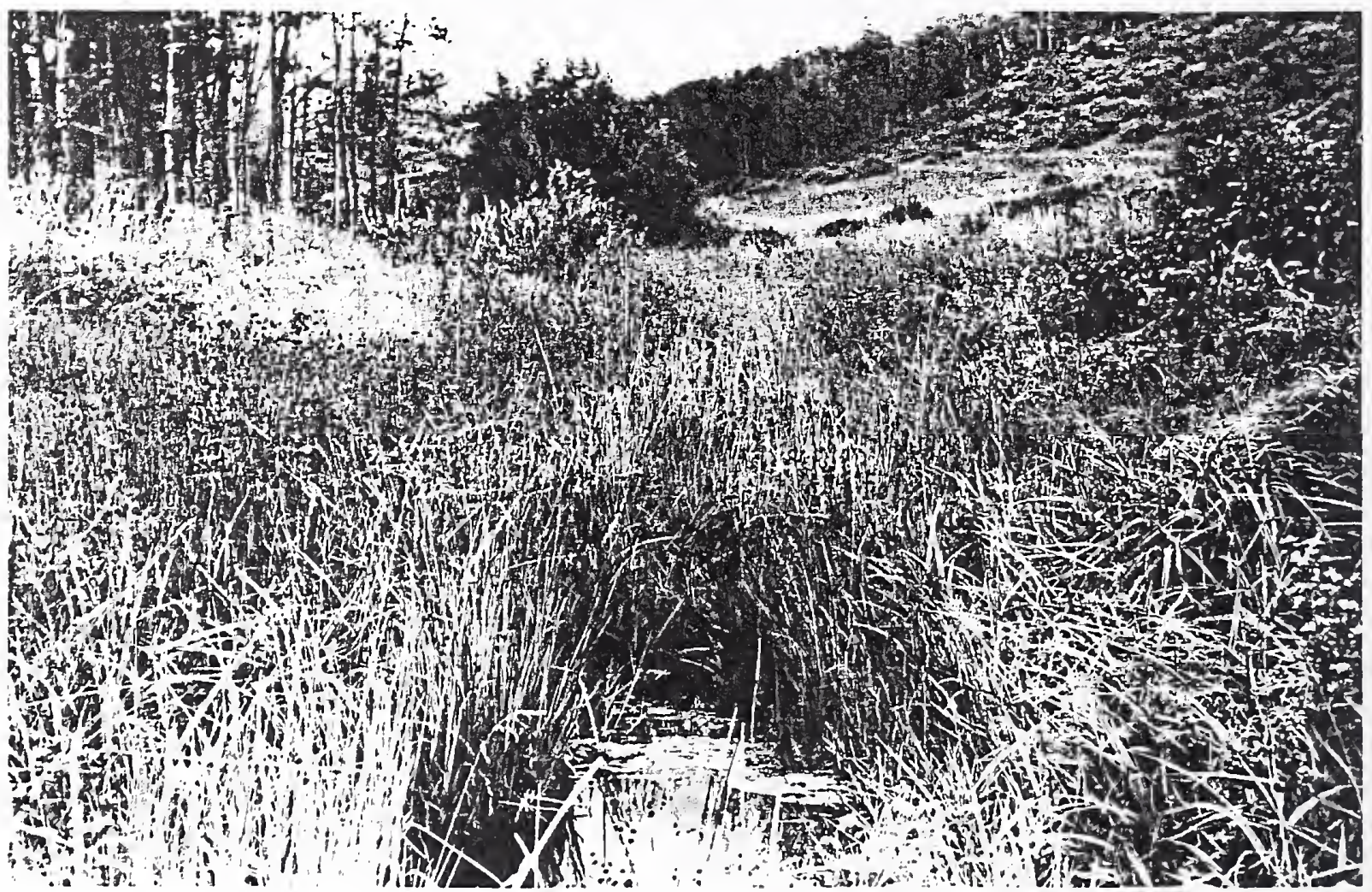

Figure 11. - Wet meadow community, Chicken Creek watersheds. 


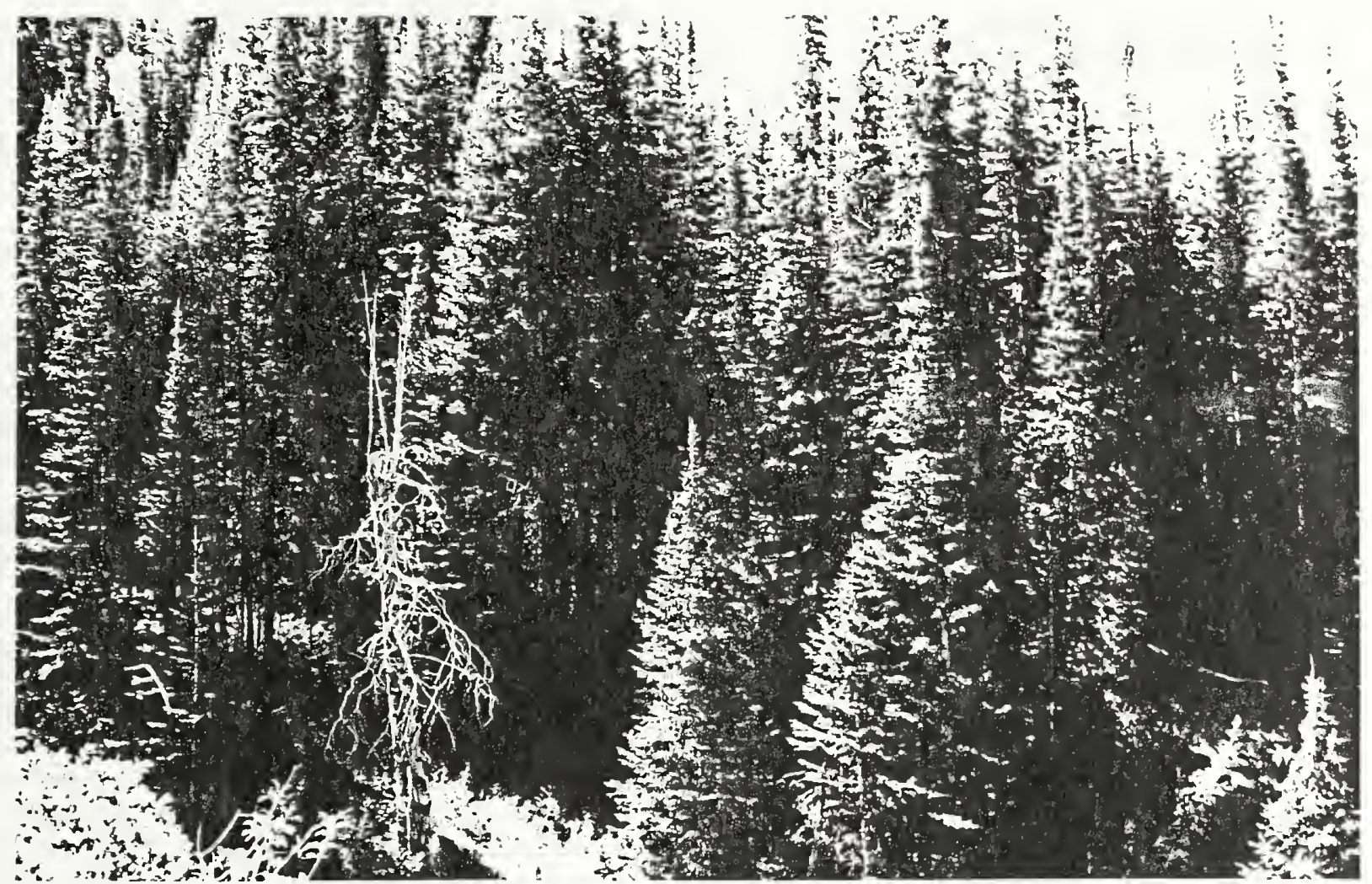

Figure 12. - Conifer community, Chicken Creek watersheds.

type occurs, more than 90 percent of the ground is covered by vegetation and litter. The dominant species in the wet meadow type are sedges and rushes, thinleaf alder, monkey flower, bluegrass, cow parsnip, false hellebore, and sphagnum.

\section{Conifer}

The conifer type (fig. 12) occupies only about 3 percent of the two study areas com- bined and is generally restricted to one northeast-facing slope of each watershed. The stands are composed of Douglas-fir, subalpine fir, and white fir, which have an average basal area of 160 square feet per acre and maximum tree height of 82 feet. In this type, litter is both deep and well dispersed, accounting for 35 percent of the ground cover. Understory vegetation includes: snowberry, aster, sweetroot, meadow rue, and vallerian. 
No studies or inventories of wildlife have been made on the two study watersheds, but several comments based on general observations seem appropriate.

The two watersheds serve as summer range for an unknown number of mule deer. Hunting pressure is heavy, primarily due to the accessibility of the area and the close proximity to high population areas along the Wasatch Front. Winter range of these animals is restricted to the lower elevations both to the east and west of the watersheds.

Beaver are quite active throughout the Farmington Canyon drainage. There are many small dams and three active lodges, one on the East Branch and two on the West Branch. These dams have a profound effect on sediment measurements by alternately trapping and then suddenly releasing prodigious amounts of these materials when dams fail. Any increased sediment caused by the recommended treatments of this study probably will be too small to be detected.
No trout have been found above the stream-gaging stations; this is probably due to the very low summer flows and associated high-water temperatures. Trout are regularly stocked in lower Farmington Creek and fishing pressure in the accessible reaches is fairly heavy for such a small stream.

Pocket gophers are among the more commonly observed rodents inhabiting the two watersheds. Their presence is marked by the many tunnel castings remaining after snowmelt and the freshly turned mounds of earth. Past research has indicated that if the aspen overstory is removed, pocket gophers may seriously deplete the remaining plant cover (Marston and Julander 1961).

Our study contains few observations on the bird populations of the area. Ruffed grouse and red-tailed hawks are known to be resident, and bald and golden eagles have been observed in winter.

A more precise inventory of the wildlife of the area is needed to measure the impact of our proposed treatment on this resource. 


\section{Soil Moisture}

Soil moisture has been measured over a period of 5 years at five sites and 6 years at an additional site. These sites on the two study watersheds represent four soil units $(12,16$, 20,21 ) and include measurements under three vegetation types (mature aspen, aspen sprouts, and grass-forb). Measurements were made to a depth of 6 feet, using a neutron moisture probe.

Although late fall rains do contribute to soil water recharge, most recharge occurs in the late spring as a result of snowmelt. The soil mantle is fully recharged at the end of the snowmelt period which may occur anytime between early May and the middle of June.

There is evidence indicating that soil moisture withdrawal begins early in the spring when the snowpack may be several feet deep. This withdrawal is difficult to assess since it is masked by snowmelt recharge. However, it is known that measurable depletion begins immediately after snowmelt and continues to increase at a rapid rate into July. Withdrawal rates are greatest in the surface 3 feet, the area of highest root concentrations. As the growing season progresses and potential evap. otranspiration increases, the actual evapotranspiration losses are limited by soil moisture availability. As the surface soils dry, the percent withdrawal from the deeper soil levels increases and is restricted to removal by deep-rooted brush and tree species.

Summer rainfall is only a small portion of the annual precipitation. These summer storms seldom recharge more than the surface few inches of soil, and this moisture is quickly lost to evaporation or transpiration.

Moisture depletion in the surface 6 feet of soil is shown in figure 13 for several combinations of vegetation and soils. The average 5-year-maximum and 5-year-minimum moisture contents are presented as the extremities of the bar graphs. Moisture depletion under the three aspen communities ranged from 6.9 to 8.5 inches, but depletion under the grass and the aspen-sprout communities was only 3.9 and 4.6 inches, respectively, for the same soil types. These relations suggest that a potential water savings of 3 to 4 area-inches

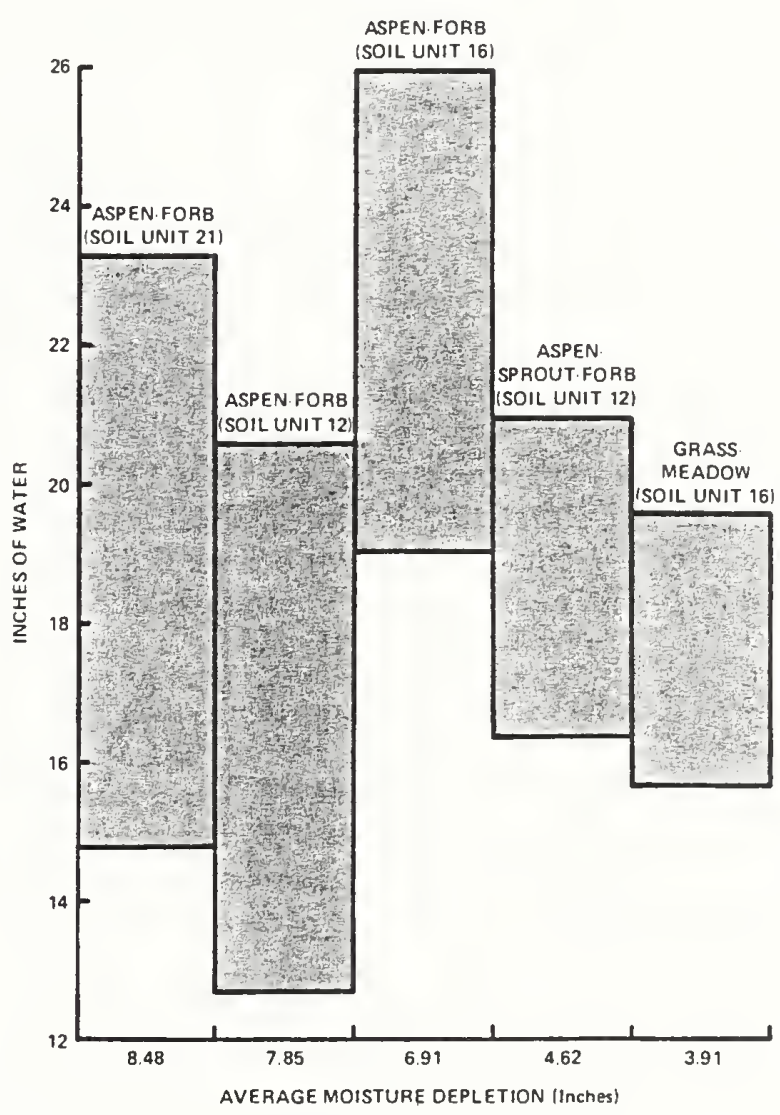

Figure 13. - A comparison of soil moisture depletion in the surface 6 feet for several soil and vegetation types. Average maximum and minimum moisture values are represented by the top and bottom of the bars. 
might be realized by changing either the species or character of existing plant communities. The primary purpose of these changes would be to reduce moisture loss below the surface 3 feet by reducing rooting depth.

If the aspen were removed, we would expect that uncontrolled sprout growth would quickly reduce the benefits of the treatment on water yields. A plot study conducted on the experimental watersheds demonstrated that soil moisture losses were reduced by 3 or more inches in each of the first 4 years following aspen clearcutting (Johnston 1969). The results of soil moisture measurements in the 0 - to 3-foot and 3- to 6-foot depths on both clearcut and mature aspen plots is presented in figure 14 for the second, third, and fourth seasons after cutting. No attempt was made to control sprouting. By the fourth year, reduction in depletion in the surface 3 feet had been largely eliminated while depletion differences in the 3- to 6-foot level remained fairly constant. The pattern of withdrawal did not change greatly from the fourth through the seventh year indicating that treatment effects may be more persistent than previously expected.

\section{Evapotranspiration}

Potential evapotranspiration (PE) computed according to the Thornthwaite method (Thornthwaite 1957), is largely based on

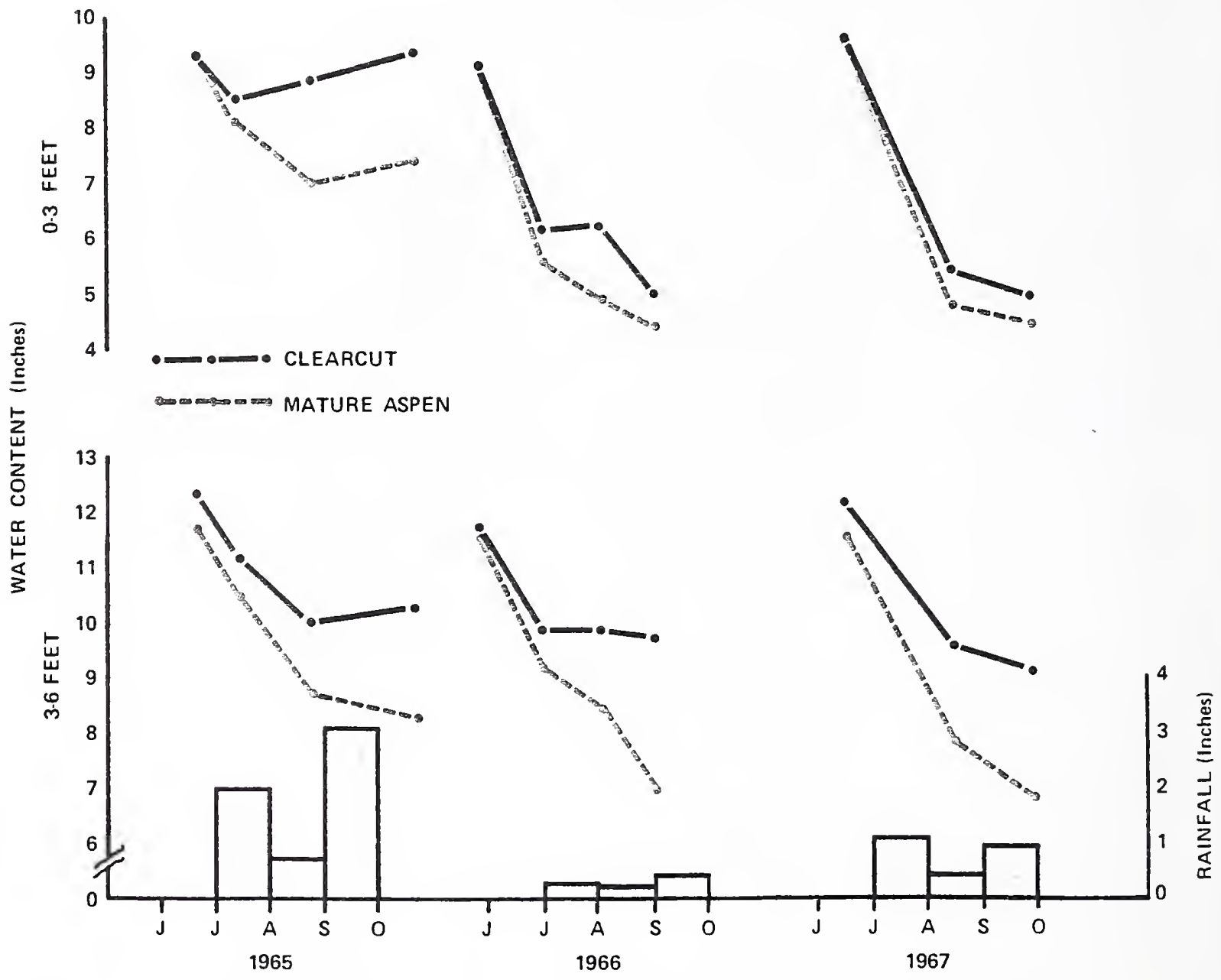

Figure 14. - Moisture content in the first 3 feet (0-3 feet) and the second 3 feet (3-6 feet) soil profile. Measurements for 1965 represent the second summer after clearcutting. 


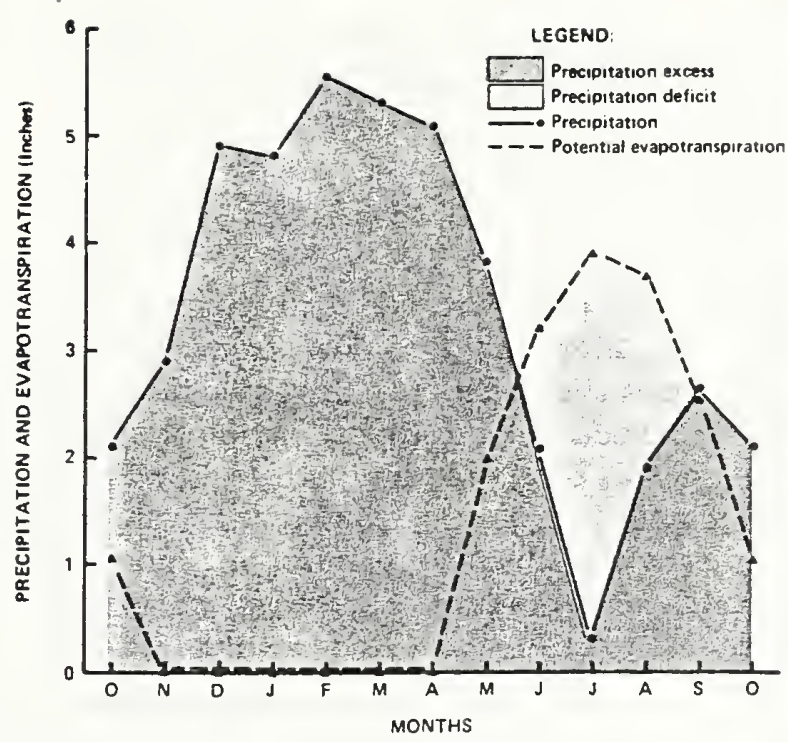

Figure 15. - Comparison of mean monthly precipitation and potential evapotranspiration for the period 1956-1959.

mean monthly temperature. $\mathrm{PE}$ is an index of heat energy available to vaporize water and is an estimate of the amount of evapotranspiration (ET) that would occur if plant and soil water were not limiting. PE is assumed to be 0 when the mean monthly temperature is below $32^{\circ} \mathrm{F}$.

$\mathrm{PE}$ values are plotted along with mean monthly precipitation in figure 15. Precipitation exceeds ET for 8 months of the year, from October through May, followed by precipitation deficit during June, July, and August, when ET exceeds precipitation. Average $\mathrm{PE}$ during the summer was 11.1 inches compared to an average rainfall of 1.45 inches per month. Rainfall and PE are about equal in September. Annual precipitation exceeds the yearly PE by 41.5 to 16.6 inches, respectively. Our computations of annual PE are 2 to 5 inches lower than presented in the Hydrologic Atlas of Utah (Jeppson and others 1968), although the same method was used. It should be noted, however, that in the Hydrologic Atlas, PE for the entire State is based on tem-

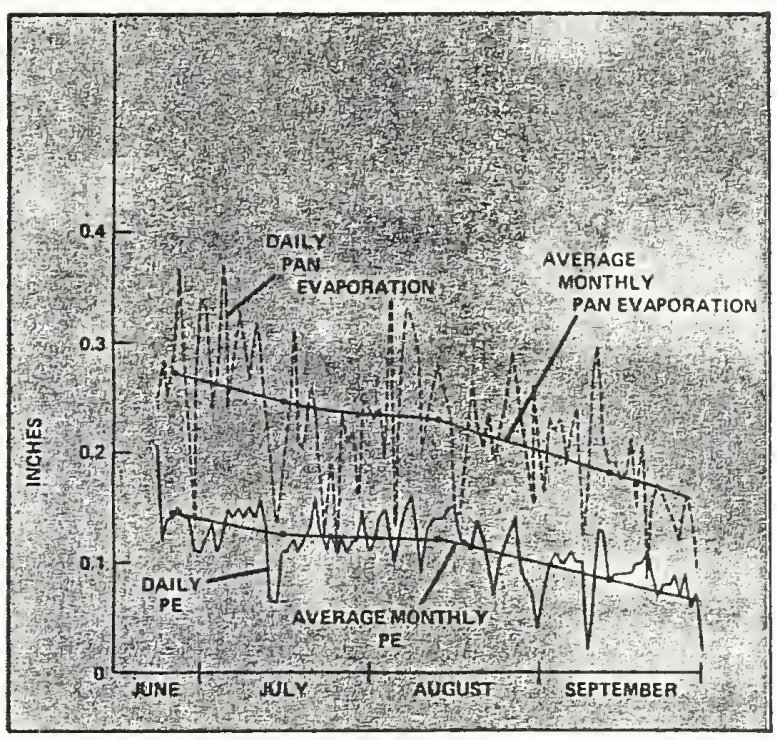

Figure 16. - Comparison of daily and average monthly values of pan evaporation and potential evapotranspiration (1962).

perature records extrapolated from valley stations.

Daily evaporation from a class "A" pan was compared with computed PE for the summer of 1962 (fig. 16). Pan evaporation fluctuated greatly in response to daily changes in climatic variables. Average pan evaporation was 0.22 inch per day, more than twice the average $\mathrm{PE}$ of 0.10 inch per day. Total values were 22.9 inches for the pan and 10.7 inches $\mathrm{PE}$. It is generally accepted that pan evaporation characteristically overestimates ET.

ET was estimated for the period May through September 1965 for two cover types, a mature aspen community and an adjacent area from which the aspen had been removed. ET was considered to be the sum of the soil moisture depletion and rainfall for the period. The estimated ET was 14.06 inches from the aspen and 10.84 inches from the grass-forb community. For the same period, calculated $\mathrm{PE}$ was 14.24 inches, which is fairly close to our estimated ET for the aspen. 


\section{Gaging Stations}

Temporary $90^{\circ}$ "V" notch weirs were operated near the present gage locations from 1952 to 1958. In 1965 a 3-foot "H" type flume with concrete block stilling well house was installed at the mouth of each watershed. Streamflow is being recorded continuously on Fisher-Porter analog-to-digital punch tape recorders at 15-minute intervals from April through October, and 30-minute intervals during the remainder of the year. The flumes have a rated head capacity of 0.02 to 2.9 feet or a maximum discharge capacity of 30 c.f.s. A heating system was developed for these stations to permit measurement of winter flows (Doty and Johnston 1967). The system consists of plywood flume covers, a 12,000 B.t.u. infrared heater mounted beneath the cover, and a small floating heater in the stilling well. The system has proven very effective in eliminating ice formation at the stations.

\section{Streamflow}

The annual streamflows from the East and West Branches of Chicken Creek are presented

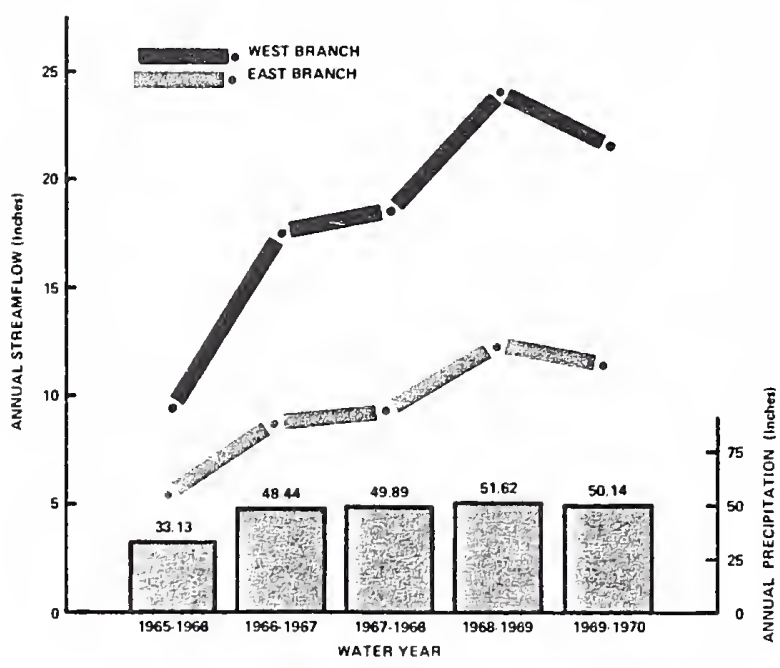

Figure 17. - Comparison of annual streamflow and annual precipitation (1965-1970), East and West Branches. in figure 17 and compared to annual precipitation. Mean annual flow from the West Branch is slightly more than twice that of the East Branch for the 5-year period, but these watersheds display rather marked fluctuations in annual flow in response to relatively small changes in annual precipitation. The West Branch also produces 36 percent more water per acre than the East Branch (table 4).

The distribution of streamflows throughout the year (timing) is often more important than the total of these flows, especially when downstream storage facilities are inadequate or lacking. Mean monthly streamflows (table 8 , Appendix) are compared in figure 18. The flows from both watersheds are very low for about 7 months of the year, usually from July through February. About 88 percent of the total flow from the two watersheds occurs during 3 months, April, May, and June in response to snowmelt. Neither watershed shows much response to the general increase in rainfall during the late summer and early fall (fig. 3 ) indicating that these rains serve to recharge the depleted soil mantle and do not immediately affect streamflow.

Annual streamflow was expressed as a percent of annual precipitation (table 5). In general, the higher the annual precipitation, the greater the percent yielded, and once again the yield from the West Branch is about twice that of the East Branch. The difference in both per acre and percent yields from the two areas may be explained by noting the topographical dissimilarity of the two areas with respect to the distribution and redistribution of precipitation. We believe that the East Branch does not effectively catch and hold the precipitation that falls on it, especially along the high ridge that forms the northwest boundary. First, it is generally accepted that rainfall diminishes near the crest of exposed ridges; this would tend to reduce the amount of rainfall intercepted by the watershed. Secondly, snowfall is redistributed on both 
Table 4. - A comparison of streamflow from the East and West Branches of Chicken Creek (water year 1966-1970)

\begin{tabular}{lcc}
\hline Unit of measurement & East Branch & West Branch \\
\hline $\begin{array}{l}\text { Mean annual flow } \\
\quad \text { inches }\end{array}$ & 9.7 & 18.7 \\
$\quad$ c.f.s. & 0.15 & 0.47 \\
$\quad \begin{array}{l}\text { c.s.m. } \\
\text { acre ft. }\end{array}$ & 0.72 & 1.23 \\
Maximum annual flow & 111.8 & 280.4 \\
$\quad$ acre ft. & 145.25 & 442.25 \\
Minimum annual flow & & \\
$\quad$ acre ft. & 66.35 & 177.83 \\
Maximum recorded flow & & \\
$\quad$ c.f.s. & 4.67 & 13.39 \\
Minimum recorded flow & & 0.001 \\
$\quad$ c.f.s.
\end{tabular}

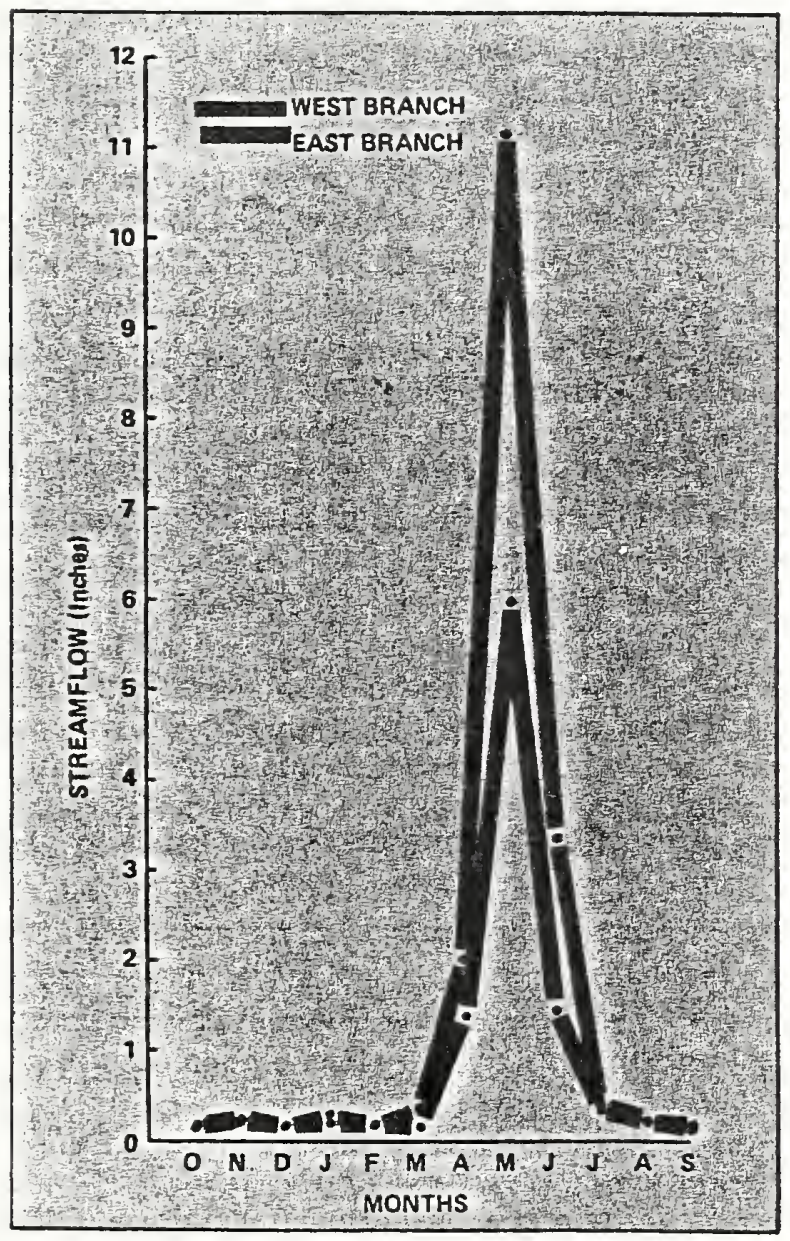

Figure 18. - Comparison of mean monthly streamflow (1965-1970), East and West Branches. watersheds by the prevailing southwest winter winds. These winds deposit deep drifts on the lee side of the ridges which form the southwest boundary of the West Branch and at the same time clear the snow from the windward side of the high ridge, which forms the north and east boundary of the East Branch. Seldom is the snow depth greater than a few inches on that high ridge during the winter, but depth increases downslope in general response to the height of the vegetation. The redistribution of snow increases the effective depth of winter precipitation on the West Branch and reduces the effective depth of winter precipitation on the East Branch. This hypothesis will be tested during the 1971-1972 winter. Forty permanent snow measurement points have been established on the two study watersheds. Snow depths and density will be measured at each point after major storms and again several dars later. These measurements should help quantify the redistribution of snow on the area.

\section{Calibration}

In all watershed studies, we must determine whether sufficient correlation exists between watersheds so that the expected change in streamflow due to treatment can be detected at a reasonable confidence level. Regres. sion equations for several different periods of streamflow data from the East versus the West Branches are presented in table 6. In these analyses the West Branch was the dependent variable.

The $R^{2}$ values are all high, indicating that most of the variation in streamflow between watersheds is accounted for in the regression. The best correlation appears to be with the 5 years of annual flows measured by the present gaging stations. When the 6 years of streamflow data measured at the "V" notch stations are included in the regression, the $R^{2}$ decreases. Individually, streamflow from the two periods fit the respective regression lines very nicely, but the two lines diverge. Perusal of the data indicates that the problem is caused by the lack of comparability of the winter flow between the two time periods. Winter flow was estimated during the time 
Table 5. - Water yielded from the East and West Branch watersheds expressed as percent of annual precipitation (1965-1970)

\begin{tabular}{|c|c|c|c|c|c|}
\hline \multirow[b]{2}{*}{ Item } & \multirow[b]{2}{*}{$1965-66$} & \multicolumn{4}{|c|}{ Water year } \\
\hline & & $1966-67$ & $1967-68$ & $1968-69$ & $1969-70$ \\
\hline & $\ldots$ & $\ldots \ldots$ & - -Percen & $\ldots \ldots$ & $\ldots \ldots$ \\
\hline East Branch & 17 & 18 & 19 & 25 & 23 \\
\hline West Branch & 29 & 36 & 38 & 47 & 44 \\
\hline Annual precipitation & 33.13 & 49.44 & 49.89 & 51.62 & 50.14 \\
\hline
\end{tabular}

that " $V$ " gages were used, based on the flow prior to freezeup. Our measurements of winter flow obtained from the heated gaging stations indicate that winter flow was materially underestimated in the past, especially from the West Branch.

We used the techniques presented by Kovner and Evans (1954) to determine the length of calibration period needed to accurately predict various levels of expected posttreatment change in streamflow. Using 5 years of streamflow data and based on an error variance of pretreatment flow of 0.714 inch, we calculated that we should be able to detect an 8 percent change in annual flow (1.48 inches) at the 95 percent confidence level. Based on these analyses, the two watersheds appear to be well calibrated, but since no treatment is planned before the summer of 1973 , the pretreatment calibration period will be extended to $6 \frac{1}{2}$ years.
How much of an increase in streamflow can we expect? This is a difficult question, and the answer depends on the type of treatment used and area to which it is applied. We know that when aspen was defoliated in southern Utah, annual streamflow from a 447 -acre treated area increased from 0.5 to 3.5 inches during the posttreatment period. If we extrapolate the water savings indicated by our plot studies (Johnston 1969, 1970) to a 100-acre treatment area, we would theoretically realize a reduction in soil moisture depletion of about 8 inches of water per acre or about 66 acre feet. If all the water saved were released as streamflow, annual flow from the West Branch would be increased about 24 percent. This extrapolation is, of course, oversimplified and subject to considerable error. It is used only to illustrate the potential for increasing water yields and to point out the need for a watershed size study.

Table 6. - Linear regression analyses using several streamflow parameters for the Chicken Creek watersheds

\begin{tabular}{|c|c|c|c|}
\hline Equation & Input & $\mathrm{R}^{2}$ & $\mathrm{~N}$ \\
\hline$Y=2.04 \times-1.377$ & Annual flow & 0.982 & 5 \\
\hline$Y=0.5447 \times+0.324$ & $\begin{array}{l}\text { Annual flow }+6 \text { yrs. of " } V \text { " notch data, } \\
\text { 1952-1958 }\end{array}$ & 0.922 & 11 \\
\hline$Y=1.858 \times+0.043$ & Monthly flow & 0.977 & 60 \\
\hline$Y=1.94 \times-0.126$ & Annual April-July high flow period & 0.970 & 5 \\
\hline$Y=2.156 \times-0.562$ & Annual August-March low flow period & 0.922 & 5 \\
\hline
\end{tabular}


Several indicators of water quality are being monitored on the watersheds. They include measurement of suspended and bedlo ad sediments, water temperature, and chemical and bacteriological quality.

\section{Sediment Measurement}

Gravimetric measurements of bedload and suspended sediment on the East and West Branch drainages indicate that good quality water is obtained from both. Nearly all of the sediment produced comes from runoff during the snowmelt period and in conjunction with summer storms. A major contributor to bedload appears to be abandoned beaver ponds which are now releasing their accumulation of sediment as the dams deteriorate.

Bedload sediment is trapped in the Polyakov type of river bottom samplers which were installed on the East and West Branches of Chicken Creek in 1967. The entire stream passes over each sampler, resulting in a 75 to 95 percent catch of the total bedload. The West Branch produces almost no bedload, only $0.07 \mathrm{lb}$. per acre per year. The East Branch produces considerably more, but still only $1.14 \mathrm{lb}$. per acre per year. The material in the bedload from both streams is primarily sand and small gravel (90 percent of it less than 3/4-inch diameter). Organic matter averages about 8 percent in each of the streams.

Both streams produce about the same amount of suspended sediment during the summer months. The highest amount recorded was only 59 parts per million (p.p.m.) from the West Branch and 48 p.p.m. from the East Branch. Suspended sediment measurements during peak spring runoff are no greater than during rainy periods during the summer.

\section{Water Temperature}

Water temperatures have been recorcied continuously near the gaging stations on each watershed since April 1971, and periodically at other locations. Water temperatures fluctuated slightly between $31.1^{\circ}$ and $35.6^{\circ} \mathrm{F}$. while the streams remained snow-covered. Beginning with snowmelt, temperatures increased until mid-August. The monthly maximum and minimum water temperatures of the two streams were within $4^{\circ} \mathrm{F}$. except during July, August, and September. At this time maximum temperatures were much higher on the West Branch. The maximum recorded temperature was $75^{\circ} \mathrm{F}$. compared to $64^{\circ} \mathrm{F}$. at the East Branch gage. Water temperatures at the highest continuously flowing springs on each watershed were fairly constant $\left(44^{\circ} \mathrm{F}\right.$.) throughout the summer.

\section{Chemical Quality}

Monitoring of various chemical properties and constituents of the water from the research area was begun in March 1971. Water samples were collected weekly until October and monthly thereafter; the samples were usually taken near the gages and occasionally from the source areas. Conductivity and $\mathrm{pH}$ were determined and samples were analyzed for the following inorganic components: calcium, magnesium, sodium, potassium, total phosphorus, nitrate, and bicarbonate.

The range of values for each parameter is listed in table 9 of the Appendix. Generally, values are higher for the West Branch than the East Branch. The exceptions are for the minimum values of conductance, magnesium, and sodium, which are slightly higher for the East Branch samples. The low conductivity values 
of both streams indicate a low level of ionic material. Bicarbonate and calcium comprise the bulk of the dissolved chemical load of the constituents measured. The $\mathrm{pH}$ values of both streams were usually about 7.5 , but these values became slightly acid during the spring high flow period.

There appears to be a general relationship between solute concentrations and discharge. Except for nitrate and potassium, the concentration of each constituent decreased during the spring high flow period and increased generally into the summer low flow period. Nitrate concentrations were very low throughout the measurement period, seldom exceeding 0.1 p.p.m. on either stream.

A more complete analysis was made on water samples collected in mid-July both near the gages and at headwater springs in each watershed. These analyses included tests for trace elements, heavy metals, biochemical demand (BOD), and total coliform bacteria; results are listed in table 10 of the Appendix. The tests indicated almost no trace elements and only small concentrations of iron, zinc, manganese, and copper. About 60 percent of the total dissolved load of each stream is contributed by bicarbonate and 98 percent by the five contributors: bicarbonate, calcium, sodium, sulfate, and chloride.

\section{Bacteriological Quality}

Bacteriological analysis of samples collected in mid-July indicated that total coliform bacteria counts were very low, ranging from less than 3 per $100 \mathrm{ml}$. at a spring on the West Branch to 120 per $100 \mathrm{ml}$. at the East Branch stream gage.

Additional water samples were collected and analyzed by research personnel from Utah State University at about 2-week intervals from mid-July to mid-October and this sampling is continuing. Bacteriological analysis included: total coliform, fecal coliform, and fecal streptococcus. There is insufficient information, at present, to indicate relationships or trends. Counts were very low and variable ( 0 to 250 per $100 \mathrm{ml}$.) except for a single sampling date in mid-August when a very large increase in all counts was noted (total coliform and fecal streptococcus, both exceeded 1,000 counts per $100 \mathrm{ml}$.). This water sample was taken immediately after a 1.88 inch rainfall and the high counts are attributed to surface runoff and flushing of beaver dams and stream channels. 
Various descriptive and hydrologic data were collected as part of the pretreatment inventory of two small watersheds (East and West Branches) in the Wasatch Range of Utah. These data will help determine the type of treatment imposed on the watershed, as well as the extent, timing, and evaluation of treatment effects on hydrologic response.

The two watersheds (137 and 219 acres) are representative of many small, predominantly aspen-covered mountain drainages in the Wasatch Range. Average precipitation is 45 inches, which is predominantly snow, and mean annual temperature is a cool $36^{\circ} \mathrm{F}$. Annual streamflow closely reflects precipitation and has varied from 10 to 24 inches on the larger area and 6 to 13 inches on the smaller area during the past 5 years. About 88 percent of streamflow occurs during the Aprilthrough-June period.
The area is geologically complex and rock material underlying the solum is deeply weathered and fractured. Soils are generally deep, except on the ridges, but available soil moisture is largely depleted throughout the depth of rooting by midsummer. Average evapotranspiration from the dense aspenforb-grass community is 15 inches during the growing season.

Soils appear to be fairly stable under the existing vegetative cover. Water quality is quite high. The highest suspended sediment measurement was 59 p.p.m. and average bedload from the two areas is only 0.07 and 1.14 lb. per acre per year. In addition, both bacteriological counts and the amount of dissolved solids are low. 
Beetle, A. A.

1970. Recommended plant names. Univ. of Wyoming, Agr. Exp. Sta. Res. J. $31.124 \mathrm{p}$.

Bell, G. L.

1952. Geology of the Northern Farmington Mountains. Utah Geological Society, Guidebook to the Geology of Utah, No. 8:38-51.

Bouyoucos, G. F.

1962. Hydrometer method improved for making particle size analysis of soils. J. Agron. 54:464-465.

Croft, A. R., and L. V. Monninger

1953. Evapotranspiration and other water losses on some aspen forest types in relation to water available for streamflow. Amer. Geophys. Union Trans. 34(4):563-574.

Doty, R. D., and R. S. Johnston

1967. A heating system for stream gaging stations. J. Soil and Water Conserv. 22(6): 251-252.

Farmer, E. E., and J. E. Fletcher

1971. Precipitation characteristics of summer storms at high-elevation stations in Utah. USDA Forest Serv. Res. Pap. INT-110, 24 p., illus.

Holmgren, A. H., and J. L. Reveal

1966. Checklist of the vascular plants of the Intermountain region. USDA Forest Serv. Res. Pap. INT-32. 160 p.

Jeppson, R. W., G. L. Ashcroft, A. L. Huber, G. V. Skogerboe, and J. M. Bagley

1968. Hydrologic Atlas of Utah. Utah State Univ. Agr. Exp. Sta. and Water Res. Lab. 306 p.

Johnston, R. S.

1969. Aspen sprout production and water use. USDA Forest Serv. Res. Note INT-89. 6 p.
Johnston, R. S.

1970. Evapotranspiration from bare, herbaceous, and aspen plots: a check on a former study. Water Resources Res. 6(1):324-327.

Johnston, R. S., R. K. Tew, and R. D. Doty

1969. Soil moisture depletion and estimated evapotranspiration on Utah mountain watersheds. USDA Forest Serv. Res. Pap. INT-67. 13 p.

Kovner, J. L., and T. C. Evans

1954. A method for determining the minimum duration of watershed experiments. Amer. Geophys. Union Trans. 35(4): 608-612.

Marston, Richard B., and Odell Julander

1961. Plant cover reductions by pocket gophers following experimental removal of aspen from a watershed area in Utah. J. Forest. 59:100-102, illus.

Peck, E. L.

1967. Influence of exposure on pan evaporation in a mountainous area. USDC Weather Bureau and Utah State Univ., Utah Water Res. Lab. $132 \mathrm{p}$.

Peck, E. L., and D. J. Pfankuch

1964. Evaporation rates in mountainous terrain. Int. Assoc. of Sci. Hydrol. Comm. for Evap. Pub. 62:267-278.

Schollenberger, C. J.

1945. Determination of soil organic matter. Soil Sci. 59:53-56.

Tew, R. K.

1969. Converting Gambel oak sites to grass reduces soil moisture depletion. USDA Forest Serv. Res. Note INT-104. 4 p.

Thornthwaite, C. W., and J. R. Mather

1957. Instructions and tables for computing potential evapotranspiration and the water balance. Drexel Inst. of Tech., Pub. in Climatology $\mathrm{X}(3)$, $311 \mathrm{p}$. 
APPENDIX 


\section{SOIL PROFILE DESCRIPTIONS}

\section{Unit 10. - Lithic Argixeroll (shallow mixed mesic)}

Parent Material: Gneiss, schist, migmatites

Slope: 18 percent, south aspect

Drainage: Well to somewhat excessively drained Elevation: $8,200 \mathrm{ft}$.
Landform: High mountain ridge, scarp slope Erosion: Inherent erosion hazärd moderate Vegetation: Low sagebrush, rabbitibrush, Indian paintbrush, carex spp.

Horizon $\begin{gathered}\text { Depth } \\ \text { (inches) }\end{gathered}$

A11 0-1 Dark yellowish brown (10YR 4/4) gravelly sandy loam, dark yellowish brown (10YR 3/4) moist, weak medium subangular blocky structure; very friable; 25 percent gravel; neutral ( $\mathrm{pH} 7.0$ ); clear smooth boundary.

A12 1-5 Dark brown to brown (10YR 4/3) gravelly loam, dark brown (10YR 3/3) moist; weak medium subangular blocky structure; slightly hard, friable; 35 percent gravel, neutral ( $\mathrm{pH} 7.0$ ); abrupt smooth boundary.

B2t 5-9 Yellowish brown $(10 \mathrm{YR} 5 / 4)$ very gravelly clay loam, dark yellowish brown (10YR 4/4) moist; moderate fine subangular blocky structure; slightly hard, firm; 75 percent gravel; neutral ( $\mathrm{pH} \mathrm{6.8);} \mathrm{abrupt} \mathrm{irregular}$ boundary.

C $\quad 9-12 \quad$ Brown (10YR 5/3) extremely cobbly loam, moderate fine subangular blocky structure; 80 percent cobble and gravel.

R 12-14+ Hard, but well fractured, bedrock of pegmatite and gneissic rocks. 


\section{Unit 11. - Pachic Cryoboroll (loamy skeletal mixed)}

Parent Material: Granite, gneiss, slate, schist Slope: 26 percent, single, west-southwest aspect Drainage: Well drained

Elevation: $8,000 \mathrm{ft}$.
Landform: Colluvial sideslope

Erosion: Slight sheet

Vegetation: Big sagebrush, rabbitbrush, ceanothus, lupine, Indian paintbrush, bushweed, yarrow, cheatgrass, and wheatgrass

Horizon $\begin{gathered}\text { Depth } \\ \text { (inches) }\end{gathered}$

A1 0-3 Dark grayish brown (10YR 4/2) sandy loam, very dark brown (10YR $2 / 2$ ) moist aggregate; very weak medium subangular blocky breaking to moderate fine granular structure; soft, friable, nonsticky, nonplastic; plentiful fine and few micro roots; 10 percent gravel; neutral ( $\mathrm{pH}$ i.0); clear smooth boundary.

A3orB1 3-9 Dark grayish brown (10YR 4/2) gravelly sandy loam, dark brown (10YR 3/3) moist aggregate; very weak medium subangular blocky breaking to moderate fine granular structure; soft, very friable, slightly sticky, slightly plastic; plentiful fine and few medium and micro roots; 15 percent gravel; neutral ( $\mathrm{pH} 7.0$ ); clear wavy boundary .

11B21 9-16 Dark brown to brown (10YR 4/3) cobbly sandy loam marginal to sandy clay loam, dark brown (10YR 3/3) moist aggregate; moderate fine subangular blocky breaking to weak very fine granular structure; slightly hard, friable, slightly sticky, slightly plastic; few thin clay films on ped faces and colloid stains on mineral grains; plentiful medium and few fine and coarse roots; 20 percent gravel and 25 percent cobble; neutral ( $\mathrm{pH} 7.0$ ); abrupt irregular boundary.

11B22t 16-26 Strong brown (7.5YR 5/6) very stony clay loam, dark brown ( 7.5 YR 4/4) moist; moderate fine subangular blocky structure; slightly hard, friable, slightly sticky, plastic, few thin clay films on ped faces; plentiful fine and medium roots; 65 percent angular stone and cobble; neutral ( $\mathrm{pH} 7.0$ ); abrupt irregular boundary.

11C1 26-35 Brown (7.5YR 5/4) very stony sandy loam, dark brown to brown (7.5YR 4/4) moist; moderate very fine granular structure; slightly hard, very friable; few fine and medium roots; 80 percent stone and cobble; neutral ( $\mathrm{pH} 7.0$ ); abrupt irregular boundary.

R 35-44 Well weathered, well fractured migmatite (composite gneiss, soft, can be cut with knife; no roots. 


\section{SOIL PROFILE DESCRIPTIONS (con.)}

\section{Unit 12. - Pachic Cryoboroll (coarse loamy mixed)}

Parent Material: Gneiss, schist, migmatites

Slope: 35 percent, single, west-sou thwest aspect

Drainage: Well drained

Elevation: $7,950 \mathrm{ft}$.
Landform: Colluvial slope

Erosion: Moderate inherent erosion hazard

Vegetation: Aspen and shrub understory with forbs and grasses

Horizon $\begin{gathered}\text { Depth } \\ \text { (inches) }\end{gathered}$ Description

01

A11

$\mathrm{A} 12$

$3-12$

B22t

$12-23$

B23

23-56

C

$56-60$

$\mathrm{R}$

$60+$
Thin layer of partially decomposed aspen leaves.

Very dark grayish brown (10YR 3/2) sandy loam; weak fine granular structure; soft, friable; plentiful micro roots and few fine roots; very few fine pores; neutral ( $\mathrm{pH} 7.0$ ); clear smooth boundary.

\section{Dark grayish brown (10YR 4/2) sandy loam; very dark grayish brown} (10YR 3/2) moist; weak medium subangular blocky breaking to moderate fine granular structure; slightly hard, friable; few fine and plentiful medium and coarse roots; very few fine vesicular pores; slightly acid ( $\mathrm{pH} 7.0)$; clear wavy boundary.

Brown (10YR 4/3) gravelly heavy sandy loam, dark brown (10YR $3 / 3$ ) moist; moderate medium subangular blocky breaking to weak fine subangular blocky structure; slightly hard, slightly firm, slightly plastic; slightly sticky; few thin clay films in pores and colloid stains on mineral grains; few fine and coarse and plentiful medium roots; plentiful micro and very fine pores; 15 percent gravel; slightly acid ( $\mathrm{pH} 6.5)$; clear wavy boundary.

Brown (7.5YR 5/2) cobbly sandy loam, dark brown (7.5YR 4/2) moist; weak coarse subangular blocky structure; slightly hard, friable, slightly sticky, slightly plastic; 15 percent cobble and gravel; slightly acid ( $\mathrm{pH} 6.5$ ); gradual wavy boundary.

Brown (7.5YR 5/2) cobbly loamy sand; massive; slightly acid ( $\mathrm{pH} 6.5$ ); abrupt irregular boundary.

Well weathered, slightly fractured parent material consisting of gneiss and schistose rocks. 
SOIL PROFILE DESCRIPTIONS (con.)

Unit 13. - Argic Pachic Cryoboroll (loamy skeletal mixed)

Parent Material: Schistose rock

Slope: 26 percent, complex, southwest aspect

Drainage: Well drained

Elevation: 8,000 ft.
Landform: Colluvial slope

Erosion: None apparent

Vegetation: Aspen, chokecherry, snowberry, columbine, lupine, yarrow, brome

$\begin{array}{ccc}\text { Depth } & \\ \text { Horizon } & \text { (inches) }\end{array}$

A11 0-1 Dark grayish brown (10YR 4/2) loam, black (10YR 2/1) moist; weak fine platy breaking to weak fine granular structure; soft, friable, slightly sticky, nonplastic; plentiful micro and few fine roots; neutral ( $\mathrm{pH} 7.0)$; clear smooth boundary.

A12 1.12 Dark grayish brown (10YR 4/2) loam; very dark brown (10YR 2/2) moist crushed; moderately fine subangular blocky breaking to moderate very fine granular structure; soft, friable, slightly sticky; plentiful micro and few fine roots; slightly acid ( $\mathrm{pH} \mathrm{6.5);} \mathrm{abrupt} \mathrm{wavy}$ boundary.

11B1t 12-21 Brown (10YR 5/3) gravelly clay loam, brown to dark brown (10YR 4/3) moist crushed; moderate fine subangular blocky breaking to moderate very fine subangular blocky structure; slightly hard, firm, sticky, plastic; common thin clay films on ped faces and as bridging and colloid stains on mineral grains; plentiful fine and medium roots; 40 percent gravel; medium acid ( $\mathrm{pH} 6.0$ ); gradual wavy boundary.

11B2t 21-33 Dark brown (7.5YR 4/4) very gravelly clay, dark brown (7.5YR 3/4) moist aggregate; strong medium blocky breaking to moderate fine subangular blocky structure; hard, firm, plastic, sticky; many moderately thick clay films on ped faces, in pores, and as bridging; plentiful fine and few medium roots; 50 percent gravel; medium acid ( $\mathrm{pH} 6.0$ ); gradual wavy boundary.

11B3t 33-40 Brown (7.5YR 5/4) very gravelly clay loam; weak medium subangular blocky structure; slightly hard, firm, slightly sticky, slightly plastic; few thin clay films as bridging; few fine roots; 75 percent gravel;

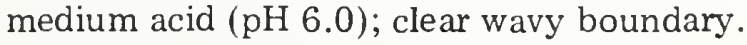

C1 40-48+ Strong brown to brown $(7.5 \mathrm{YR} 5 / 5)$ very cobbly sandy loam; massive; very friable; very few fine roots; 75 percent cobble and gravel; medium acid ( $\mathrm{pH} \mathrm{6.0)}$. 
SOIL PROFILE DESCRIPTIONS (con.)

Unit 14. - Typic Cryochrept (fine loamy mixed)

Parent Material: Granite, gneiss, and schistose rock

Slope: 47 percent, north aspect

Drainage: Well drained

Elevation: $7,900 \mathrm{ft}$.
Landform: Colluvial slope

Erosion: None apparent

Vegetation: Subalpine fir, snowberry, lupine, western coneflower

\begin{tabular}{lll}
\hline Horizon & $\begin{array}{c}\text { Depth } \\
\text { (inches) }\end{array}$ & Description \\
\hline
\end{tabular}

01

02

A1

A2

B21t

$8-17$

B22t

$17-27$

B3

$27-33$

$\mathrm{R}$

$33-40+$
Partially decomposed needles and twigs.

Black, well decomposed needles and twigs.

Brown (10YR 4/3) very fine sandy loam, dark brown (10YR 3/3) moist; moderate medium subangular blocky breaking to moderate fine granular structure; slightly hard, friable; plentiful medium and few fine roots; slightly acid ( $\mathrm{pH} 6.5$ ); clear wavy boundary.

Light brown (7.5YR 6/4) gravelly sandy loam, dark brown to brown (7.5YR 4/2) moist; weak medium subangular blocky breaking to moderate very fine granular structure; slightly hard, friable; plentiful coarse and medium and few fine roots; 20 percent gravel; strongly acid (pH 5.5); clear wavy boundary.

Brown (7.5YR 4.4/2) gravelly heavy sandy loam, dark brown (7.5YR $3 / 2$ ) moist crushed; weak medium subangular blocky breaking to moderate fine subangular blocky structure; slightly hard, friable, slightly sticky; few thin clay films on ped faces and in pores; few fine and plentiful coarse and medium roots; 30 percent gravel; medium acid ( $\mathrm{pH}$ 6.0); gradual irregular boundary.

Brown (7.5YR 5/2) cobbly sandy clay loam marginal to clay loam, brown (7.5YR 4.6/2) moist crushed; weak fine subangular blocky breaking to weak fine granular structure; slightly hard, friable, sligh tly sticky; slightly plastic; few thin clay films on ped faces and in pores; few coarse and plentiful medium roots; 25 percent cobble; medium acid ( $\mathrm{pH} 5.8$ ); clear irregular boundary.

Brown (7.5YR 4.4/2) cobbly sandy clay loam marginal to clay loam, dark brown (7.5YR 3/2) moist crushed; weak medium subangular blocky structure; slightly hard, friable, slightly sticky; colloid stains on mineral grains; few medium roots; 30 percent cobble; slightly acid (pH 6.5); abrupt wavy boundary.

Brown (7.5 YR 5/4); highly weathered schistose rock; high in mica (dominantly biotite). 


\section{SOIL PROFILE DESCRIPTIONS (con.)}

Unit 16. - Typic Cryochrept (fine loamy mixed)

Parent Material: Alluvium

Slope: 8 percent, complex, west aspect

Drainage: Moderately well drained to imperfectly drained

Elevation: $7,700 \mathrm{ft}$.
Landform: Meadow

Erosion: None apparent

Vegetation: Snowberry (scattered) grass, tarweed

\begin{tabular}{|c|c|c|}
\hline Horizon & $\begin{array}{l}\text { Depth } \\
\text { (inches) }\end{array}$ & Description \\
\hline $\mathrm{A} 1$ & $0-2$ & $\begin{array}{l}\text { Reddish brown ( } 5 \mathrm{YR} 5 / 4 \text { ) loam, dark reddish brown ( } 5 \mathrm{YR} 3 / 3 \text { ) moist, } \\
\text { moderate coarse platy breaking to strong medium subangular blocky } \\
\text { structure; slightly hard, friable, few micro and fine roots; neutral } \\
\text { (pH 7.0); clear smooth boundary. }\end{array}$ \\
\hline B1 & $2-14$ & $\begin{array}{l}\text { Reddish brown ( } 2.5 \mathrm{YR} 4 / 4) \text { clay loam, dark reddish brown ( } 2.5 \mathrm{YR} \\
3 / 4 \text { ) moist; strong medium angular blocky breaking to strong fine } \\
\text { subangular blocky structure; hard, firm, slightly sticky, slightly } \\
\text { plastic; common moderately thick clay films as bridging; few fine } \\
\text { and medium roots; many fine and medium pores; neutral (pH } 6.8 \text { ); } \\
\text { clear wavy boundary. }\end{array}$ \\
\hline B21t & $14-22$ & $\begin{array}{l}\text { Reddish brown ( } 2.5 \mathrm{YR} 4 / 4) \text { clay loam, dark reddish brown ( } 2.5 \mathrm{YR} \\
3 / 4) \text { moist; moderate medium subangular blocky structure; very } \\
\text { hard, firm, slightly sticky, slightly plastic; many moderately thick } \\
\text { clay films on ped faces and as bridging; many fine and medium pores; } \\
\text { neutral (pH 6.8); gradual wavy boundary. }\end{array}$ \\
\hline$B 22 t$ & $22-34$ & $\begin{array}{l}\text { Weak red (10YR } 5 / 4) \text { sandy clay loam, dusky red (10YR } 3 / 4) \text { moist; } \\
\text { moderate medium subangular blocky structure; hard, firm, slightly } \\
\text { sticky, slightly plastic; many moderately thick clay films on ped faces } \\
\text { and as bridging; many fine and medium pores; neutral ( } \mathrm{pH} 7.0) \text {; } \\
\text { gradual wavy boundary. }\end{array}$ \\
\hline B3 & 34.55 & $\begin{array}{l}\text { Weak red (10YR } 5 / 4) \text { sandy clay loam, dusky red }(10 \mathrm{R} 3 / 4) \text { moist, } \\
\text { distinct mottles on ped faces, reddish gray }(10 \mathrm{R} 5 / 1) \text { and reddish } \\
\text { brown ( } 5 \text { Y R } 5 / 4) \text {; moderate fine subangular blocky breaking to } \\
\text { moderate fine granular structure; slightly hard, friable, slightly sticky; } \\
\text { many moderately thick clay films on ped faces and as bridging; very } \\
\text { few fine roots; neutral (pH } 7.0) \text {; clear irregular boundary. }\end{array}$ \\
\hline $\mathrm{C} 1$ & $55-65$ & $\begin{array}{l}\text { Dark reddish gray ( } 10 \mathrm{YR} 4 / 1 \text { ) sandy loam; massive; slightly acid } \\
\text { (pH } 6.5 \text { ); yellowish red mottles ( } 5 \mathrm{YR} 5 / 6) \text {. }\end{array}$ \\
\hline
\end{tabular}


SOIL PROFILE DESCRIPTIONS (con.)

\section{Unit 18. - Aquic Argic Cryoboroll (fine mixed)}

Parent Material: Gneiss and shale

Slope: 25 percent

Drainage: Poorly to somewhat poorly drained

Elevation: $8,000 \mathrm{ft}$.
Landform: Landflows

Erosion: None apparent

Vegetation: Aspen, snowberry, gooseberry

\section{Depth \\ Horizon (inches) Description}

A11 0-1 Dark brown to brown (10YR 4/3) loam, dark brown $(10$ YR 3/3) moist; weak fine piaty breaking to moderate very fine granular structure; slightly hard, friable; plentiful fine and micro roots; few micro and very fine interstitial pores; neutral; abrupt smooth boundary.

A12 1-11 Brown (10YR 5/3) heavy loam, dark brown (10YR 4/3) moist; moderate medium subangular blocky breaking to moderate medium granular structure; slightly hard, friable, slightly sticky, slightly plastic; plentiful fine and few micro and medium roots; common very fine interstitial pores; neutral; clear smooth boundary.

B21t 11-15 Light brown (7.5YR 6/4) sandy clay, dark brown to brown (7.5YR 4/4) moist; strong medium subangular blocky structure; hard, firm, sticky, plastic; common moderately thick clay films on ped faces, in pores, and as bridging; plentiful medium and coarse and few fine roots;

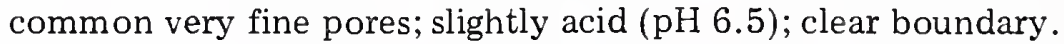

B22t 15-18 Light brown (7.5YR 6/4) gravelly clay, brown (7.5YR 5/4) moist; strong coarse subangular blocky structure; hard, firm, sticky, plastic; many moderately thick to thick clay films on ped faces and as bridging; plentiful medium and coarse and few fine roots; 20 percent gravel; slightly acid ( $\mathrm{pH} 6.4$ ); abrupt irregular boundary.

11B21tg 18.25 Yellowish brown (10YR 5/6) gravelly clay, brown (10YR 4/3) moist; strong coarse angular blocky structure; very hard, very firm, sticky, plastic; common medium distinct very dark grayish brown (10YR 3/2) and grayish brown $(2.5 \mathrm{Y} 5 / 2)$ mottles; common moderately thick clay films on ped faces; few coarse and fine and plentiful medium roots; 25 percent gravel; slightly acid ( $\mathrm{pH} 6.5$ ); gradual wavy boundary.

11B22tg 25-47+ Yellowish brown (10YR 5/6) stony clay; strong coarse angular blocky structure; common medium distinct olive gray, olive and grayish brown mottles; common moderately thick clay films on ped faces; plentiful medium and few fine roots; 40 percent stone and gravel; slightly acid (pH 6.4). 


\section{SOIL PROFILE DESCRIPTIONS (con.)}

\section{Unit 19. - Typic Cryoboroll (fine mixed)}

Parent Material: Silstone, shale conglomerate Slope: 27 percent, complex, north aspect Drainage: Well to moderately well drained Elevation: $7,800 \mathrm{ft}$.
Landform: Scarp slope

Erosion: None apparent

Vegetation: Snowberry, canna sage, lupine, geranium, mountain brome, carex, tarweed

Horizon $\begin{gathered}\text { Depth } \\ \text { (inches) }\end{gathered}$ Description

A1 $0-1 \frac{1}{2} \quad$ Reddish brown (5YR 5/4) loam, reddish brown (5YR 5/4) moist; weak coarse platy structure; hard, friable, slightly sticky, slightly plastic; plentiful very fine roots; common coarse tubular and fe: medium tubular pores; neutral ( $\mathrm{pH} 7.0$ ); abrupt smooth boundary .

A3 1/2-4 Reddish brown (2.5YR 4/4) light clay loam, dark reddish brown (2.5YR 3/4) moist; weak coarse platy breaking to moderate medium subangular blocky structure; hard, firm, slightly sticky, slightly plastic; plentiful fine roots; few fine and medium pores; neutral; abrupt smooth boundary.

B21t 4-15 Red (2.5YR 4/6) clay loam, dark red (2.5YR 3/6) moist; weak coarse prismatic breaking to weak medium subangular blocky structure; hard, firm, sticky, plastic; abundant very fine, plentiful fine, and few medium roots; few fine and coarse interstitial and common medium pores; neutral ( $\mathrm{pH} 7.0$ ); clear wavy boundary.

B22t 15-23 Red (2.5YR 5/6) clay loam, red (2.5YR 4/6) moist; weak medium prismatic breaking to moderate medium subangular blocky structure; hard, firm, slightly sticky, slightly plastic; common thin clay films on ped faces, in pores, and colloid stains on mineral grains; plentiful fine, few very fine and medium roots; common medium interstitial pores; neutral; gradual wavy boundary.

B23t 23-40 Red (10R 5/6) clay, red (10 R 4/6) moist; moderate fine prismatic breaking to moderate very fine subangular blocky structure; very hard, very firm, very sticky, very plastic; common moderately thick clay films on ped faces and as bridging; plentiful fine and few medium roots; common medium and few fine pores; neutral ( $\mathrm{pH} 7.0$ ); abrupt irregular boundary.

B1b 40-55 Red (10R 4/6) sandy clay loam, dark red (10R 3/6) moist; weak medium subangular blocky breaking to moderate fine granular structure; few thin clay films as bridging; few fine and medium roots; common fine and few medium pores; 3 " thick clay pockets 7 " -8 " in length as lenses; neutral ( $\mathrm{pH} 7.0$ ); clear irregular boundary. 
SOIL PROFILE DESCRIPTIONS (con.)

Unit 19. - Typic Cryoboroll (fine mixed) (con.)

B21tb 55-71

Red (10R 5/6) clay, red (10R 4/6) moist; moderate coarse angular blocky breaking to moderate fine subangular blocky structure; extremely hard, very firm, very sticky, very plastic; common thin clay films on ped faces, in pores, and as bridging; plentiful medium roots; few medium and fine pores; neutral ( $\mathrm{pH} \mathrm{7.0).}$

$\mathrm{B} 22 \mathrm{tb} \quad 71-80$

Red (10R 5/6) clay, red (10R 4/6) moist; strong coarse angular blocky structure; very hard, very firm, very sticky, very plastic; common moderately thick clay films on ped faces and as bridging; neutral ( $\mathrm{pH} 7.0)$.

$\mathrm{C} 1$

$80-95$

Light red (10R 6/6) silty clay loam, red (10R 4/6) moist; massive; very hard, firm, sticky, and plastic. 
SOIL PROFILE DESCRIPTIONS (con.)

Unit 20. - Lithic Cryoboroll (shallow mixed)

Parent Material: Medium to fine sandstone and siltstone

Slope: 8-10 percent, complex, south-southwest aspect

Drainage: Well drained

Elevation: $7,800 \mathrm{ft}$.
Landform: Residual

Erosion: Slight sheet

Vegetation: Big sagebrush, rabbitbrush, lupine, Indian paintbrush, fescue

A1 $\quad 1-4 \quad$ Reddish brown (5YR 5/3) gravelly sandy loam, reddish brown (5YR 4/3) moist; weak medium subangular blocky breaking to weak fine granular structure; slightly hard, friable; few micro and plentiful fine and medium roots; 20 percent gravel; slightly effervescent; clear wavy boundary.

B2t $\quad 4.8 \quad$ Red (2.5YR 4/6) cobbly sandy clay loam, dark red (2.5YR 3/6) moist; moderate medium subangular blocky breaking to moderate fine granular structure; hard, firm, sticky, plastic; common thin clay films on ped faces and as bridging; few micro and fine and very few medium roots; 20 percent cobble and gravel; effervescent; clear wavy boundary.

B3 8-15 Red (10R 5/6) very cobbly loam, red (10R 4/6) moist; moderate fine subangular blocky structure; slightly hard, friable, slightly sticky, common thin clay films on ped faces and as bridging; plentiful fine and few medium and coarse roots; 75 percent cobble and gravel; effervescent; abrupt irregular boundary.

R 15-24 Well weathered parent rock, noncalcareous; sandy siltstones and thin fissile shale, well fractured, has some translocated clay in fractures and on underside of cobble. 


\section{SOIL PROFILE DESCRIPTIONS (con.)}

\section{Unit 21. - Argic Cryoboroll (fine loamy mixed)}

Parent Material: Shale, conglomerate Slope: 38 percent, complex, north aspect Drainage: Well drained Elevation: $7,800 \mathrm{ft}$.
Landform: Residual slope

Erosion: None apparent

Vegetation: Aspen, grass, forbs

\begin{tabular}{|c|c|c|}
\hline Horizon & $\begin{array}{l}\text { Depth } \\
\text { (inches) }\end{array}$ & Description \\
\hline
\end{tabular}

A1 $\quad 0-3$

A3

$3-11$

B1 11-25

B21t 25-45

$\mathrm{B} 22 \mathrm{t} \quad 45-64$

11B23t $64-76$
Dark brown (7.5YR 3/2) loam, very dark brown (7.5YR 2/2) moist; moderate very fine granular structure; soft, friable, abundant micro and plentiful fine roots; neutral ( $\mathrm{pH} 7.0$ ); clear smooth boundary .

Reddish brown (5YR 4/3) loam, dark reddish brown (5YR 3/3) moist; weak medium subangular blocky breaking to moderate very fine granular structure; slightly hard, friable; plentiful micro and medium, abundant fine, and few coarse roots; neutral ( $\mathrm{pH} 7.0)$; clear smooth boundary.

Reddish brown (2.5YR 4/4) clay loam, dark reddish brown (2.5YR $2 / 4$ ) moist; moderate medium subangular blocky structure; slightly hard, firm, slightly sticky, slightly plastic; common moderately thick clay films on ped faces and in pores; plentiful coarse and medium and few fine roots; common fine pores; neutral ( $\mathrm{pH} 7.0$ ); gradual smooth boundary.

Reddish brown (2.5YR 4/4) clay loam, dark reddish brown (2.5YR 2/4) moist; strong medium subangular blocky structure; hard, firm, sticky, plastic; many moderately thick clay films on ped faces; plentiful medium and few fine and coarse roots; common medium pores; neutral ( $\mathrm{pH} 7.0)$; gradual smooth boundary.

Red (10R 4/6) sandy clay loam, dark red (10R 3/6) moist; weak coarse subangular blocky structure; slightly hard, firm, sticky, plastic; few thin clay films as bridging; few fine roots; common

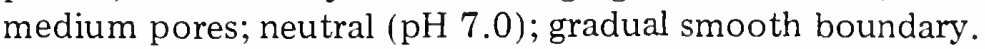

Red (10R 5/6) gravelly clay loam, red (10R 4/6) moist; weak coarse angular blocky structure; hard, firm, sticky, plastic; few thin clay films on ped faces, in pores, and as bridging; very few fine roots; common fine pores; 25 percent angular gravel; neutral ( $\mathrm{pH} 7.0$ ); gradual wavy boundary. 


\section{SOIL PROFILE DESCRIPTIONS (con.)}

\section{Unit 22. - Typic Cryoboroll (clayey skeletal mixed)}

Parent Material: Mixed siltstone, shale, schist, pegmatite

Slope: 20 percent, complex northeast aspect

Drainage: Well drained

Elevation: $7,700 \mathrm{ft}$.
Landform: Mudslide or rockslide

Erosion: None apparent

Vegetation: "Scrubby" aspen, snowberry, wyethia, tarweed

\begin{tabular}{|c|c|c|}
\hline Horizon & $\begin{array}{l}\text { Depth } \\
\text { (inches) }\end{array}$ & Description \\
\hline $\mathrm{A} 1$ & $0-2$ & $\begin{array}{l}\text { Brown ( } 7.5 \text { YR } 5 / 2 \text { ) gravelly light clay loam, dark brown ( } 7.5 \text { YR } \\
\text { 4/2) moist; weak fine granular structure; hard, friable, slightly } \\
\text { sticky, slightly plastic; very few micro roots; common fine pores; } 25 \\
\text { percent gravel; slightly acid ( } \mathrm{pH} 6.5 \text { ); abrupt irregular boundary. }\end{array}$ \\
\hline B1 & $2-12$ & $\begin{array}{l}\text { Light reddish brown ( } 5 \text { YR } 6 / 3 \text { ) cobbly clay loam, reddish brown } \\
\text { (5YR } 5 / 3 \text { ) moist; moderate medium subangular blocky structure; } \\
\text { hard, firm, sticky, plastic; plentiful fine and few medium roots; } 25 \\
\text { percent angular gravel and cobble; medium acid ( } \mathrm{pH} 6.0 \text { ); gradual } \\
\text { irregular boundary. }\end{array}$ \\
\hline B21t & $12-24$ & $\begin{array}{l}\text { Light reddish brown ( } 5 \mathrm{YR} 6 / 4 \text { ) very cobbly clay; strong medium } \\
\text { subangular blocky structure; very hard, firm, sticky, plastic; common } \\
\text { moderately thick to thin clay films on ped faces; plentiful medium and } \\
\text { few fine roots; } 65 \text { percent angular cobble; very strongly acid (pH } 5.0 \text { ); } \\
\text { gradual irregular boundary. }\end{array}$ \\
\hline$B 22 t$ & $24-35$ & $\begin{array}{l}\text { Reddish yellow (5YR 6/6) very cobbly clay, yellowish red ( } 5 \text { YR } 5 / 6 \text { ) } \\
\text { moist; moderate fine angular blocky structure; very hard, firm, sticky, } \\
\text { plastic; many thick clay films on ped faces and in pores, pressure } \\
\text { faces on few peds; very few medium roots; } 85 \text { percent angular cobble } \\
\text { and stone; very strongly acid (pH } 4.5 \text { ); abrupt irregular boundary. }\end{array}$ \\
\hline $\mathrm{C}$ & $35+$ & $\begin{array}{l}\text { Well weathered to partially decomposed rock fragments consisting of } \\
\text { pegmatites, gneiss, and schist in a clayey matrix; no oriented clays; } \\
\text { considerable micaceous material in the matrix. }\end{array}$ \\
\hline
\end{tabular}


Table 7. - Laboratory analysis of Chicken Creek soils as shown on Soil Classification Map

\begin{tabular}{|c|c|c|c|c|c|c|c|c|c|c|}
\hline \multirow[b]{2}{*}{ Unit } & \multirow[b]{2}{*}{ Horizon } & \multirow[b]{2}{*}{ Depth } & \multicolumn{3}{|c|}{ Soil texture ${ }^{1}$} & \multirow{2}{*}{$\begin{array}{l}\text { Organic } \\
\text { matter }\end{array}$} & \multirow{2}{*}{$\begin{array}{c}\text { Rock }>2 \mathrm{~mm} . \\
\text { by weight }\end{array}$} & \multicolumn{2}{|c|}{ Moisture content } & \multirow{2}{*}{$\begin{array}{c}\text { Bulk } \\
\text { density }\end{array}$} \\
\hline & & & Sand & Silt & Clay & & & $1 / 3 \mathrm{~atm}$ & $15 \mathrm{~atm}$. & \\
\hline & & (Inches) & $\cdots$ & $\ldots$. & $\ldots$. & - Perce & $n t \ldots \ldots$ & $\ldots \ldots$ & $\ldots . .$. & \\
\hline \multirow[t]{5}{*}{10} & A11 & $0-1$ & 65.8 & 20.6 & 13.6 & 9.9 & 59.4 & 12.0 & 9.5 & $\cdots$ \\
\hline & $\mathrm{A} 12$ & $1-5$ & 60.6 & 25.2 & 14.2 & 4.6 & 49.7 & 10.1 & 6.6 & $\cdots$ \\
\hline & $\mathrm{B} 2 \mathrm{t}$ & $5-9$ & 53.4 & 26.4 & 20.2 & 2.5 & 45.4 & 9.8 & 7.7 & - \\
\hline & $\mathrm{C}$ & $9-12$ & 53.0 & 25.0 & 22.0 & 2.0 & 45.6 & 11.2 & 7.3 & - \\
\hline & $\mathrm{R}$ & $12-14+$ & & & & & & & & \\
\hline \multirow[t]{6}{*}{11} & A1 & $0-3$ & 67.0 & 19.8 & 13.2 & 3.9 & 18.0 & 9.6 & 3.8 & 0.55 \\
\hline & $\mathrm{A} 3$ or $\mathrm{B} 1$ & $3-9$ & 62.6 & 22.6 & 14.8 & 2.9 & 16.1 & 8.9 & 3.2 & 1.25 \\
\hline & 11B21 & $9-16$ & 66.6 & 18.6 & 14.8 & 1.2 & 34.5 & 8.0 & 4.1 & 1.24 \\
\hline & $11 \mathrm{~B} 22 \mathrm{t}$ & $16-26$ & 69.2 & 19.0 & 11.8 & 1.3 & 19.7 & 7.4 & 2.6 & - \\
\hline & $11 \mathrm{C} 1$ & $26-35$ & 79.6 & 13.2 & 7.2 & 0.3 & 14.3 & 5.3 & 1.8 & $\cdots$ \\
\hline & $\mathrm{R}$ & $35-44$ & 82.6 & 11.8 & 5.6 & - & 2.2 & 4.1 & 1.6 & -- \\
\hline \multirow[t]{6}{*}{12} & A11 & $0-3$ & 62.6 & 21.2 & 16.2 & 3.2 & 17.8 & 11.0 & 4.2 & 0.54 \\
\hline & $\mathrm{A} 12$ & $3-12$ & 58.0 & 26.0 & 16.0 & 2.7 & 22.7 & 8.9 & 5.6 & 1.07 \\
\hline & $\mathrm{B} 22 \mathrm{t}$ & $12-23$ & 56.2 & 25.2 & 18.6 & 1.0 & 29.6 & 9.0 & 3.9 & 1.28 \\
\hline & B23 & $23-56$ & 65.0 & 22.2 & 12.8 & 0.4 & 32.8 & 8.2 & 3.3 & 1.38 \\
\hline & $\mathrm{C}$ & $56-60$ & 70.0 & 20.4 & 9.6 & - & 29.4 & 6.9 & 3.1 & 1.28 \\
\hline & $\mathrm{R}$ & $60+$ & & & & & & & & \\
\hline \multirow[t]{6}{*}{13} & A11 & $0-1$ & 50.4 & 32.2 & 17.4 & 10.8 & 33.8 & 19.4 & 10.8 & 0.37 \\
\hline & $\mathrm{A} 12$ & $1-12$ & 39.4 & 37.8 & 22.8 & 4.2 & 23.1 & 13.7 & 8.1 & 1.22 \\
\hline & $11 \mathrm{~B} 1 \mathrm{t}$ & $12-21$ & 53.2 & 29.6 & 17.2 & 0.9 & 45.5 & 9.6 & 4.5 & 1.28 \\
\hline & $11 \mathrm{~B} 2 \mathrm{t}$ & $21-33$ & 51.8 & 27.8 & 20.4 & 0.5 & 51.4 & 10.0 & 5.1 & - \\
\hline & 11B3t & $33-40$ & 51.0 & 27.0 & 22.0 & 0.6 & 48.8 & 8.9 & 4.8 & 1.27 \\
\hline & $\mathrm{C} 1$ & $40-48+$ & 50.6 & 27.0 & 22.4 & 0.5 & 51.6 & 9.1 & 5.1 & - \\
\hline \multirow[t]{6}{*}{14} & $\mathrm{~A} 1$ & $0-2$ & - & - & - & -- & - & - - & -- & 0.41 \\
\hline & A2 & $2-8$ & 56.4 & 27.0 & 16.6 & 2.3 & 25.8 & 10.6 & 5.5 & 0.95 \\
\hline & $\mathrm{B} 21 \mathrm{t}$ & $8-17$ & 58.6 & 24.2 & 17.2 & 2.5 & 30.1 & 9.7 & 4.5 & 0.86 \\
\hline & $\mathrm{B} 22 \mathrm{t}$ & $17-27$ & 55.0 & 27.8 & 17.2 & 1.9 & 31.4 & 11.0 & 7.0 & 1.01 \\
\hline & B3 & $27-33$ & 58.6 & 24.2 & 17.2 & 0.8 & 32.9 & 9.4 & 5.3 & 1.18 \\
\hline & $\mathrm{R}$ & $33-40+$ & 78.6 & 11.2 & 10.2 & $-\cdot$ & 55.7 & 6.8 & 5.1 & - \\
\hline \multirow[t]{5}{*}{16} & $\mathrm{~A} 1$ & $0-2$ & - & - & - - & - & $\cdots$ & - & $-\cdot$ & 0.66 \\
\hline & B1 & $2-14$ & 43.2 & 28.6 & 28.2 & 2.8 & 6.9 & 11.0 & 6.9 & 1.30 \\
\hline & $\mathrm{B} 21 \mathrm{t}$ & $14-22$ & 46.6 & 25.0 & 28.4 & 1.6 & 7.5 & 10.3 & 6.3 & 1.37 \\
\hline & $B 22 t$ & $22-34$ & 58.0 & 19.6 & 22.4 & 0.6 & 9.3 & 7.2 & 3.7 & 1.55 \\
\hline & B3 & $34-55$ & 47.4 & 22.4 & 30.2 & 0.4 & 5.0 & 9.5 & 5.8 & 1.75 \\
\hline
\end{tabular}


Table 7. - Laboratory analysis of Chicken Creek soils (con.)

\begin{tabular}{|c|c|c|c|c|c|c|c|c|c|c|}
\hline \multirow[b]{2}{*}{ Unit } & \multirow[b]{2}{*}{ Horizon } & \multirow[b]{2}{*}{ Depth } & \multicolumn{3}{|c|}{ Soil texture ${ }^{1}$} & \multirow{2}{*}{$\begin{array}{l}\text { Organic } \\
\text { matter }^{2}\end{array}$} & \multirow{2}{*}{$\begin{array}{c}\text { Rock }>2 \mathrm{~mm} \text {. } \\
\text { by weight }\end{array}$} & \multicolumn{2}{|c|}{ Moisture content } & \multirow{2}{*}{$\begin{array}{l}\text { Bu:k } \\
\text { density }\end{array}$} \\
\hline & & & Sand & Silt & Clay & & & $1 / 3 \mathrm{~atm}$ & $15 \mathrm{~atm}$. & \\
\hline & & (Inches) & $\ldots$. & $\cdots$ & $\cdots$ & - Perce & $n t \ldots .$. & $\cdots \cdots$ & ..... & \\
\hline \multirow[t]{6}{*}{18} & A11 & $0-1$ & 50.2 & 31.6 & 18.2 & 7.3 & 14.9 & 16.0 & 7.6 & 0.48 \\
\hline & $\mathrm{A} 12$ & $1-11$ & 44.8 & 33.8 & 21.4 & 4.5 & 9.4 & 12.0 & 6.5 & 0.05 \\
\hline & $\mathrm{B} 21 \mathrm{t}$ & $11-15$ & 46.8 & 26.2 & 27.0 & 1.5 & 12.8 & 10.8 & 6.8 & 1.44 \\
\hline & $\mathrm{B} 22 \mathrm{t}$ & $15-18$ & 49.8 & 23.2 & 27.0 & 1.2 & 12.8 & 10.7 & 6.1 & - \\
\hline & B23tg & $18-25$ & 59.8 & 14.8 & 25.4 & 1.3 & 42.3 & 10.0 & 4.1 & 1.37 \\
\hline & $\mathrm{Cg}$ & $21-30$ & 56.2 & 19.4 & 24.4 & 1.4 & 52.3 & 7.4 & 7.1 & $\cdots$ \\
\hline \multirow[t]{9}{*}{19} & $\mathrm{~A} 1$ & $0-1^{1 / 2}$ & 41.2 & 33.0 & 25.8 & 2.7 & 0.9 & 12.2 & 6.1 & 0.61 \\
\hline & A3 & $11 / 2-4$ & 35.4 & 35.2 & 29.4 & 2.9 & 0.3 & 11.7 & 7.7 & 1.13 \\
\hline & $\mathrm{B} 21 \mathrm{t}$ & 4-15 & 34.6 & 35.0 & 30.4 & 2.3 & 0.3 & 10.4 & 8.5 & 1.45 \\
\hline & $B 22 t$ & $15-23$ & 40.2 & 32.4 & 27.4 & 1.6 & 0.8 & 10.1 & 8.0 & 1.54 \\
\hline & $\mathrm{B} 23 \mathrm{t}$ & $23-40$ & 30.8 & 28.8 & 40.4 & 1.0 & 0.1 & 10.8 & 3.9 & - \\
\hline & $\mathrm{B} 1 \mathrm{~b}$ & $40-55$ & 55.2 & 23.4 & 21.4 & 0.4 & 0.3 & 8.0 & 5.9 & - \\
\hline & $\mathrm{B} 21 \mathrm{tb}$ & $55-71$ & 26.8 & 31.8 & 41.4 & $\cdots$ & 0.4 & 11.6 & 7.9 & 1.60 \\
\hline & $\mathrm{B} 22 \mathrm{tb}$ & $71-80$ & 22.2 & 37.2 & 38.6 & $-\cdot$ & 0.11 & 11.8 & 8.1 & - \\
\hline & $\mathrm{C} 1$ & $80-95$ & 13.4 & 42.0 & 44.6 & $\cdots$ & 40.8 & 11.0 & 8.6 & $\cdots$ \\
\hline \multirow[t]{5}{*}{20} & Ap & $0-1$ & 44.8 & 31.6 & 23.6 & 6.7 & 19.1 & 12.5 & 6.3 & 0.48 \\
\hline & $\mathrm{A} 1$ & $1-4$ & 52.4 & 28.2 & 19.4 & 5.4 & 26.2 & 12.4 & 8.2 & 1.13 \\
\hline & $B 2 t$ & 4.8 & 49.0 & 31.2 & 19.8 & 3.3 & 37.7 & 10.8 & 7.1 & 1.45 \\
\hline & B3 & 8.15 & 47.4 & 32.6 & 20.0 & 2.0 & 40.3 & 10.1 & 6.5 & 1.27 \\
\hline & $\mathrm{R}$ & $15-24$ & 51.4 & 30.2 & 18.4 & 1.8 & 55.3 & 9.6 & 6.5 & - \\
\hline \multirow[t]{6}{*}{21} & $\mathrm{~A} 1$ & 0.3 & 40.4 & 36.4 & 23.2 & 8.4 & 3.4 & 12.8 & 13.0 & 0.39 \\
\hline & A3 & $3-11$ & 38.4 & 36.6 & 25.0 & 6.6 & 3.0 & 14.0 & 12.7 & 0.98 \\
\hline & B1 & $11-25$ & 35.0 & 33.8 & 31.2 & 3.0 & 5.5 & 15.8 & 10.9 & - \\
\hline & $\mathrm{B} 21 \mathrm{t}$ & $25-45$ & 35.0 & 32.8 & 32.2 & 2.0 & 6.0 & 11.4 & 9.1 & 1.27 \\
\hline & $\mathrm{B} 22 \mathrm{t}$ & $45-64$ & 49.0 & 21.6 & 29.4 & 0.7 & 12.0 & 8.4 & 6.7 & $\cdots$ \\
\hline & $11 \mathrm{~B} 23 \mathrm{t}$ & $64-76$ & 44.8 & 22.8 & 32.4 & $\cdots$ & 28.6 & 10.1 & 7.1 & $-\cdot$ \\
\hline
\end{tabular}

${ }^{1}$ Texture: duplicate textural analyses were made on bulk samples using the "Improved Hydrometer Method" (Bouyoucos 1962).

${ }^{2}$ Organic Matter: the potassium permanganate test was used to determine the percent organic matter for each horizon (Schollenberger 1945). 
Table 8. - Streamflow from the Chicken Creek watersheds

\begin{tabular}{|c|c|c|c|c|c|c|}
\hline \multirow[b]{2}{*}{ Month } & \multirow[b]{2}{*}{$1965-66$} & \multirow[b]{2}{*}{$1966-67$} & \multicolumn{2}{|c|}{ Water year } & \multirow[b]{2}{*}{$1969-70$} & \multirow[b]{2}{*}{ Avg. } \\
\hline & & & $1967-68$ & $1968-69$ & & \\
\hline & \multicolumn{6}{|c|}{$\ldots \ldots \ldots \ldots \ldots \ldots$. $\ldots \ldots \ldots$ Inches $\ldots \ldots \ldots \ldots$} \\
\hline & \multicolumn{6}{|c|}{ WEST BRANCH } \\
\hline October & 0.10 & 0.07 & 0.09 & 0.48 & 0.16 & 0.18 \\
\hline November & .16 & .17 & .12 & .43 & .21 & .22 \\
\hline December & .25 & .10 & .13 & .30 & .14 & .18 \\
\hline January & .18 & .11 & .13 & .32 & .74 & .30 \\
\hline February & .15 & .12 & .23 & .26 & .22 & .20 \\
\hline March & .26 & .29 & .33 & .36 & .56 & .36 \\
\hline April & 3.41 & .52 & 1.02 & 4.55 & .54 & 2.01 \\
\hline May & 4.73 & 11.09 & 11.31 & 14.42 & 14.35 & 11.18 \\
\hline June & .42 & 4.87 & 5.00 & 2.12 & 4.35 & 3.35 \\
\hline July & .05 & .42 & .22 & .96 & .37 & .40 \\
\hline August & .02 & .05 & .21 & .09 & .68 & .21 \\
\hline September & .03 & .04 & .10 & .05 & .17 & .08 \\
\hline TOTAL YEAR & 9.78 & 17.85 & 18.88 & 24.35 & 21.99 & 18.67 \\
\hline
\end{tabular}

Inches

$\begin{array}{lrrrrrr}\text { October } & 0.06 & 0.08 & 0.10 & 0.23 & 0.15 & 0.12 \\ \text { November } & .11 & .20 & .14 & .23 & .20 & .18 \\ \text { December } & .13 & .11 & .07 & .14 & .09 & .11 \\ \text { January } & .13 & .05 & .06 & .12 & .17 & .11 \\ \text { February } & .12 & .04 & .12 & .11 & .10 & .10 \\ \text { March } & .28 & .09 & .13 & .16 & .09 & .07 \\ \text { April } & 2.74 & .18 & .50 & 2.89 & .24 & 1.31 \\ \text { May } & 1.80 & 6.02 & 6.52 & 7.28 & 7.76 & 5.88 \\ \text { June } & .26 & 1.84 & 1.51 & .87 & 2.30 & 1.36 \\ \text { July } & .07 & .22 & .15 & .47 & .35 & .25 \\ \text { August } & .04 & .11 & .19 & .12 & .15 & .12 \\ \text { September } & .05 & .06 & .10 & .04 & .18 & .09 \\ \text { TOTAL YEAR } & 5.79 & 9.01 & 9.57 & 12.68 & 11.79 & 9.07\end{array}$


Alder, thinleaf (Alnus tenuifolia)

Aspen (Populus tremuloides)

Blackcurrant, Western (Ribes petiolare)

Chokecherry, common (Prunus virginiana)

Fir, Douglas (Pseudotsuga menziesii)

Fir, subalpine (Abies lasiocarpa)

Fir, white (Abies concolor)

Hollygrape (Mahonia repens)

Honeysuckle, bearberry (Lonicera involucrata)

Manzanita, common (Arctostaphylos manzanita)
Maple, bigtooth (Acer grandidentatum)

Oak, Gambel (Quercus gambelii)

Rabbitbrush, Douglas (Chrysothamnus viscidiflorus)

Rabbitbrush, rubber (Chrysothamnus nauseosus)

Rose, woods (Rosa woodsii)

Sagebrush, big (Artemisia tridentata)

Serviceberry, Saskatoon (Amelanchier alnifolia)

Snowberry (Symphoricarpos sp.)

Willow (Salix sp.)

\section{GRASS AND GRASSLIKE}

Bluegrass, annual (Poa annua)

Bluegrass, Canada (Poa compressa)

Bluegrass, Kentucky (Poa pratensia)

Brome, cheatgrass (Bromus tectorum)

Brome, California (Bromus carinatus)

Brome, smooth (Bromus inermis)

Brookgrass, common (Catabrosa aquatica)

Bulrush, panicled (Scirpus microcarpus)

Junegrass, prairie (Koeleria cristata)

Mannagrass (Glyceria sp.)
Needlegrass, Letterman (Stipa lettermani)

Orchardgrass (Dactylis glomerata)

Rush, Baltic (Juncus balticus)

Rush, few-flowered spike (Eleocharis pauciflorus)

Sedge (Carex sp.)

Sedge, ovalhead (Carex festivella)

Timothy, alpine (Phleum alpinum)

Wheatgrass (Agropyron sp.)

Wheatgrass, Western (Agropyron, smithii)

Wildrye, blue (Elymus glaucus)

\section{FORBS}

Agoseris, orange (Agoseris aurantiaca)

Aster (Aster sp.)

Balsamroot, cutleaf (Balsamorhiza macrophylla)

Bastardtoadflax, common (Comandra umbellata)

Bedstraw, catchweed (Galium aparine)

Bittercress, heartleaf (Cardamine cordifolia)

Bluebell, mountain (Mertensia ciliata)

Bogorchid, white (Habenaria dilatata)

Buckwheat, wild (Eriogonum sp.)

Buttercup (Ranunculus gmelinii)

Camass, common (Camassia quamash)
Checkermallow, New Mexican (Sidalcea neomexican Chlorocrambe (Chlorocrambe hastata)

Collomia (Collomia sp.)

Collomia, narrowleaved (Collomia linearis)

Coneflower, Western (Rudbeckia occidentalis)

Cowparsnip, common (Heracleum lanatum)

Dock, curly (Rumex crispus)

False hellebore, California (Veratrum californicum)

Figwort, lanceleaf (Scrophularia lanceolata)

Geranium, Fremont (Geranium fremontii)

Geranium, Richardson (Geranium richardsonii) 
COMMON AND SCIENTIFIC NAMES OF SPECIES

(Holmgren and Reveal 1966; Beetle 1970)

(con.)

FORBS (con.)

Gianthyssop (Agastachi urticifolia)

Gilia, skyrocket (Gilia aggregata)

Goldenrod (Solidago sp.)

Gromwell, wayside (Lithospermum ruderale)

Groundsmoke (Gayophytum sp.)

Groundsel, butterweed (Senecio serra)

Hawksbeard (Crepis sp.)

Horsetail, Kansas (Equisetum kansanum)

Paintbrush, desert Indian (Castilleja chromos)

Knotweed, Douglas (Polygonum douglasii)

Larkspur, Nelson (Delphinium nelsoni)

Lomatium, Nuttall (Lomatium nuttallii)

Lupine (Lupinus sp.)

Meadowrue, Fendler (Thalictrum fendleri)

Milkvetch, Utah (Astragalus utahensis)

Mimulus (Mimulus tilingi)

Monkshood (Aconitum columbianum)

Onion (Allium sp.)

Orobanche (Orobanche uniflora)

Osmorhiza (Osmorhiza occidentalis)
Owlclover, yellow (Orthocarpus luteus) Pachistima, myrtle (Pachistima myrsinites) Peavine, thickleaf (Lathyrus lanszwertii) Penstemon, Leonard (Penstemon leonardi) Penstemon, stubflower (Penstemon breviflor Penstemon, Wasatch (Penstemon cyananthu: Pepperweed, clasping (Lepidium perfoliatur Polemonium, Western (Polemonium occiden Pussytoes, small leaf (Antennaria parvifolia) Salsify, yellow (Tragopogon dubius) Sandspurry, red (Spergularia rubra) Starwort, chickweed (Stellaria media) Stickweed, European (Lappula echinata) Stonecrop, wormleaf (Sedum stenopetalum) Tansymustard, pinnate (Descurainia pinnata) Tansymustard, Western (Descurainia incisa) Tarweed, cluster (Madia glomerata) Valerian, Western (Valeriana occidentalis) Wyethis, mulesear (Wyethia amplexicaulis) 
Table 9. - Range of values for water quality parameters measured between March 1 and October 12, 1971

\begin{tabular}{lcccrr}
\hline & \multicolumn{2}{c}{ East Branch } & & \multicolumn{2}{c}{ West Branch } \\
\cline { 2 - 3 } \cline { 5 - 6 } Item & Min. & Max. & & Min. & Max. \\
\hline Conductivity & & & & \\
$\quad$ (micro mhos. per cm.) & 70 & 253 & & & \\
pH & 6.4 & 7.8 & & 6.6 & 8.4 \\
Calcium (p.p.m.) & 5.0 & 19.9 & & 12.4 & 36.0 \\
Magnesium (p.p.m.) & 1.8 & 5.1 & & 0.9 & 6.7 \\
Sodium (p.p.m.) & 4.6 & 14.0 & & 3.1 & 12.8 \\
Potassium (p.p.m.) & 0 & 3.5 & & 0 & 7.0 \\
Phosphorous (total, p.p.m.) & 0.01 & 0.18 & & 0.01 & 0.14 \\
Nitrates (p.p.m.) & 0 & 0.15 & & 0 & 0.15 \\
Bicarbonates (p.p.m.) & 22.0 & 76.0 & & 40.0 & 94.0 \\
\end{tabular}


Table 10. - Results of water analysis of samples collected from the sources and near the gages of East and West Chicken Creek, July 19, 1971

\begin{tabular}{|c|c|c|c|c|}
\hline \multirow[b]{2}{*}{ Item } & \multicolumn{2}{|c|}{ East Branch } & \multicolumn{2}{|c|}{ West Branch } \\
\hline & Source & Gage & Source & Gage \\
\hline \multicolumn{5}{|l|}{ Conductivity } \\
\hline (micro mhos. per $\mathrm{cm}$. ) & 231.20 & 253.10 & 182.80 & 342.10 \\
\hline $\mathrm{pH}$ & 7.10 & 7.10 & 7.04 & 7.05 \\
\hline \multicolumn{5}{|l|}{ Total dissolved solids } \\
\hline @ $221^{\circ} \mathrm{F}$ & 148.00 & 162.00 & 118.00 & 219.00 \\
\hline Total hardness $\left(\mathrm{CaCO}_{3}\right)^{1}$ & 52.00 & 56.00 & 55.50 & 102.00 \\
\hline Total alkalinity $\left(\mathrm{CaCO}_{3}\right)$ & 72.00 & 78.00 & 58.00 & 112.00 \\
\hline Bicarbonate $\left(\mathrm{HCO}_{3}\right)$ & 87.20 & 94.50 & 70.20 & 135.00 \\
\hline Calcium (Ca) & 17.60 & 20.08 & 14.05 & 32.00 \\
\hline Carbonate $\left(\mathrm{CO}_{3}\right)$ & 1.30 & 2.30 & 1.00 & 1.40 \\
\hline Chloride $(\mathrm{Cl})$ & 6.00 & 10.00 & 6.00 & 14.00 \\
\hline Copper $(\mathrm{Cu})$ & 0.30 & 0.05 & 0.02 & 0.01 \\
\hline Fluoride $(F)$ & $<0.01$ & $<0.01$ & $<0.01$ & 0.01 \\
\hline Iron (total Fe) & 0.08 & 0.42 & 0.20 & 0.45 \\
\hline Iron (filtered $\mathrm{Fe}$ ) & 0.06 & 0.36 & 0.20 & 0.36 \\
\hline Magnesium (Mg) & 1.90 & 1.40 & 5.08 & 5.20 \\
\hline Manganese (Mn) & 0 & 0.80 & 0.01 & 0.09 \\
\hline Nitrate $\left(\mathrm{NO}_{3}\right)$ & 0.10 & 0.16 & 0.12 & 0.14 \\
\hline Nitrite $\left(\mathrm{NO}_{2}\right)$ & 0 & 0.05 & 0.01 & 0.01 \\
\hline Kjeldahl nitrogen (TKN) & 0.25 & 1.02 & 0.40 & 0.69 \\
\hline Ammonia nitrogen $\left(\mathrm{NH}_{3}\right)$ & 0.20 & 0.75 & 0.25 & 0.53 \\
\hline Organic nitrogen & 0.05 & 0.27 & 0.15 & 0.16 \\
\hline Phosphate (total P) & 0.02 & 0.06 & 0.02 & 0.03 \\
\hline Potassium $(\mathrm{K})$ & 9.00 & 9.15 & 5.10 & 6.00 \\
\hline Silica $\left(\mathrm{SiO}_{2}\right)$ & 0 & 0.90 & 0 & 0.35 \\
\hline Sodium $(\mathrm{Na})$ & 16.00 & 18.00 & 8.00 & 19.00 \\
\hline Sulfate $\left(\mathrm{SO}_{4}\right)$ & 10.50 & 9.50 & 9.15 & 8.00 \\
\hline Zinc $(\mathrm{Zn})$ & 0.02 & 0.04 & 0.02 & 0.02 \\
\hline Temperature $\left({ }^{\circ} \mathrm{F}.\right)$ & 45.70 & 59.9 & 44.50 & 65.3 \\
\hline \multicolumn{5}{|l|}{ Biochemical oxygen } \\
\hline demand (BOD) & 0.30 & 1.20 & 0.40 & 0.60 \\
\hline \multicolumn{5}{|l|}{ Total coliform bacteria } \\
\hline (per $100 \mathrm{ml})$. & 21 & 120. & $<3$ & 25 \\
\hline Discharge (c.f.s.) & & 0.06 & & 0.10 \\
\hline
\end{tabular}

${ }^{1}$ Results are listed as parts per million unless otherwise noted. In addition, the following were not found in the water sampled: Aluminum (Al), Arsenic (As), Barium (Ba), Boron (B), Cadmium (Cd), Chromium (Cr), Cyanide (Cn), Lead (Pb), Mercury (Hg), Ortho phosphate (P), Selenium (Se), and Silver (Ag). 


\section{- DEPTH OF SURFACE LAYER - VELOCITY OF SECOND LAYER}


DEPTH OF SURFACE LAYER

LEGEND:

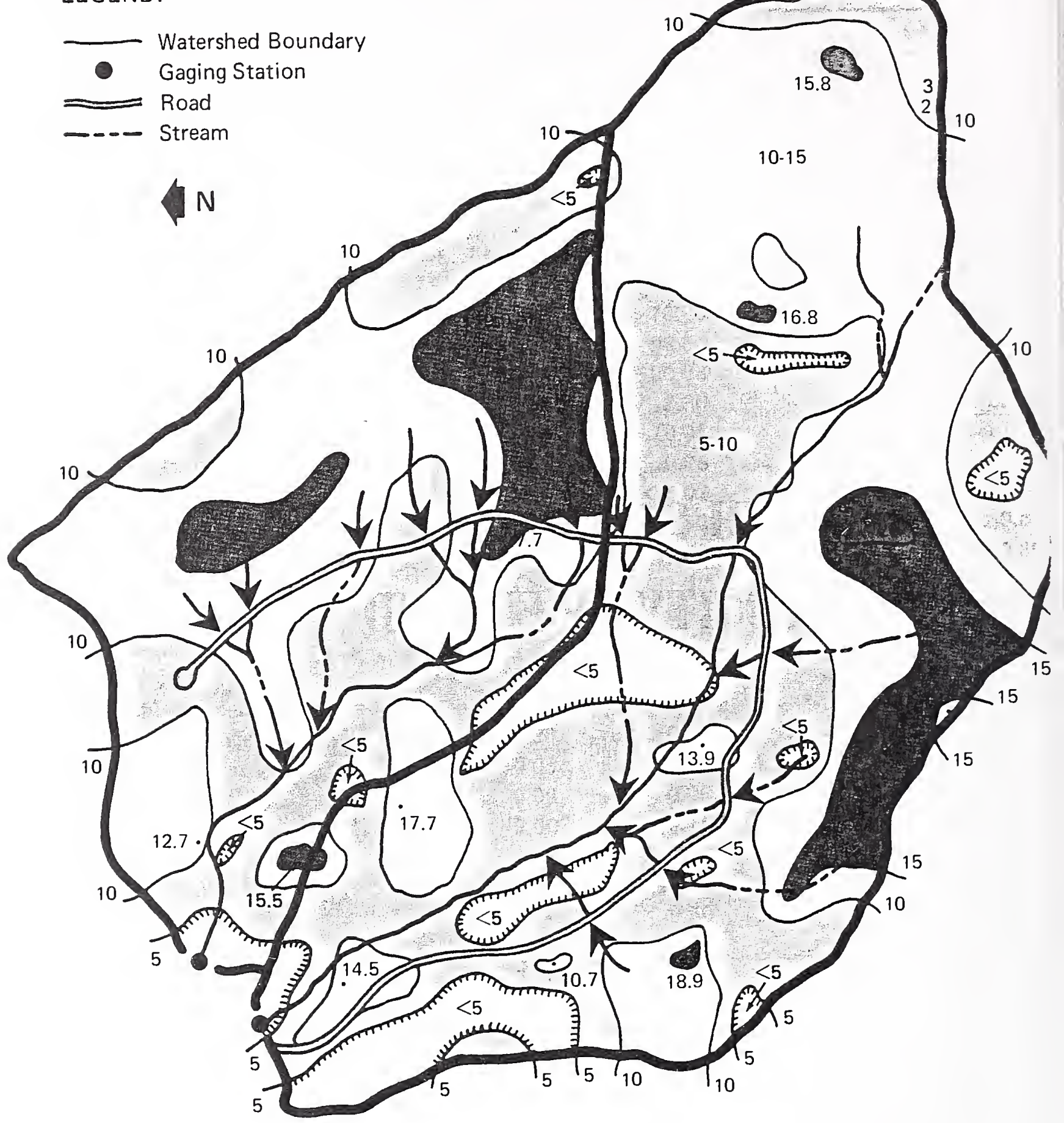

DEPTH (ft.)

$\begin{array}{llll}\square & \square & \\ \square & & 10-15 \\ & 5.10 & 15-20\end{array}$


VELOCITY OF SECOND LAYER

LEGEND:

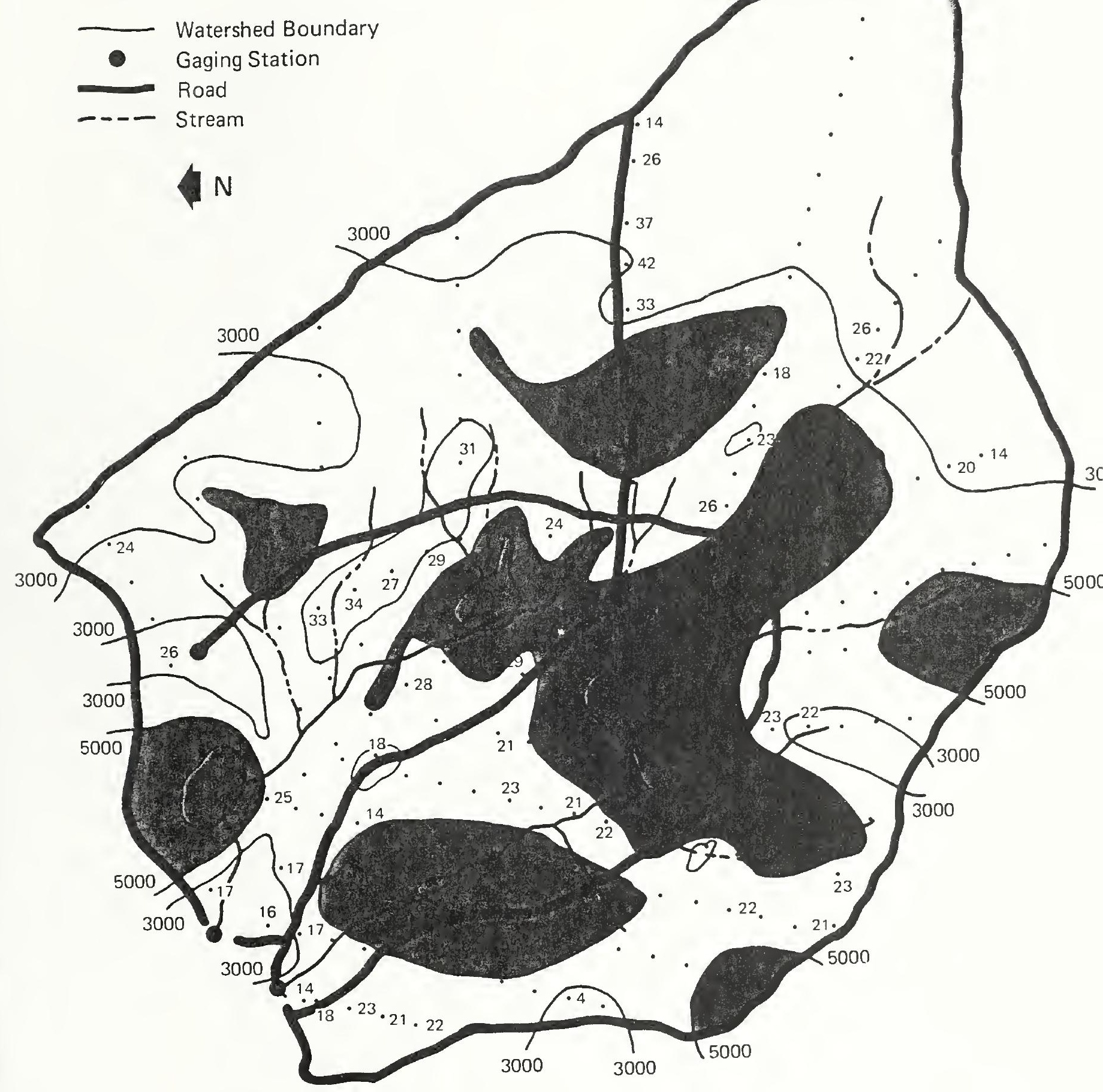

VELOCITY (f.p.s.)

\begin{tabular}{llll}
\hline & $<3000$ & 5.8000 \\
$\square$ & $3-5000$ & $\square^{2}$ & $>8000$
\end{tabular}




\section{- SOIL CLASSIFICATION MAP - VEGLTATION TYPE MAP}


SOIL CLASSIFICATION MAP

LEGEND:

Watershed Boundary
$\oplus \quad$ Gaging Station

(11) Soil Type

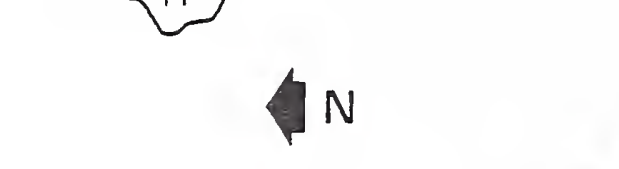


VEGETATION TYPE MAP

LEGEND:

Gaging Station
Road
5 Vegetation Type

(Numbers refer to minor variations in vegetation types and are not otherwise referred to in this paper)
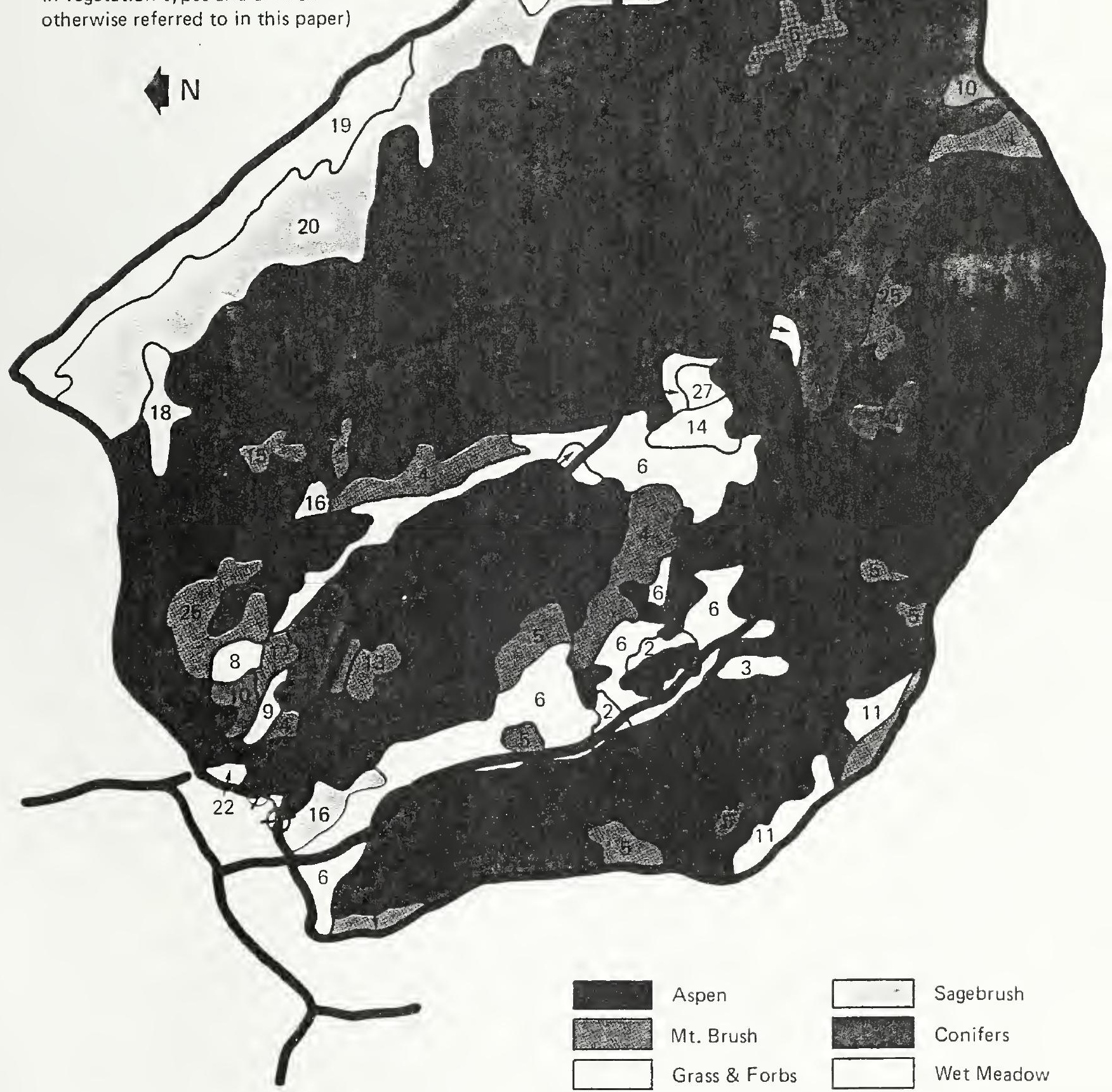

Sagebrush

Conifers

Wet Meadow 


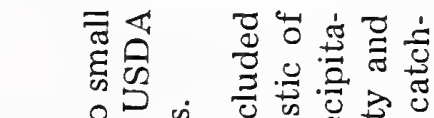

入

○े

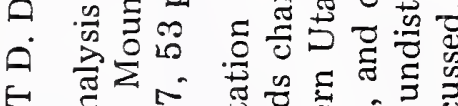

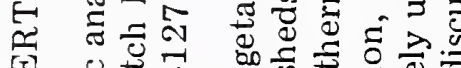

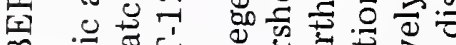

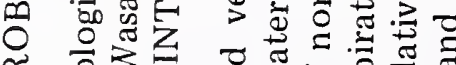

モ

จ

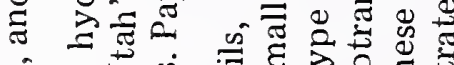

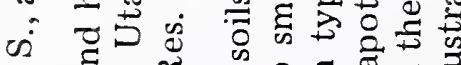

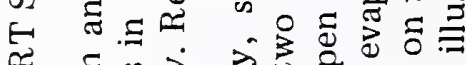

ज्ञ

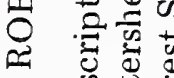

z

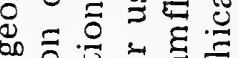

范

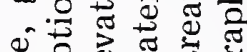

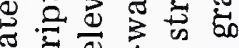

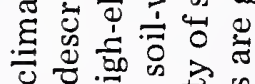

疍

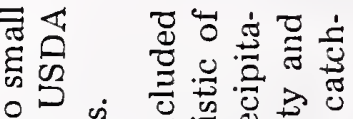

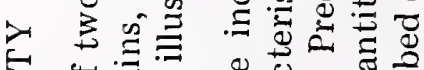

○े

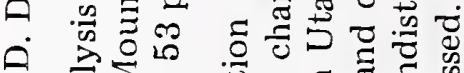

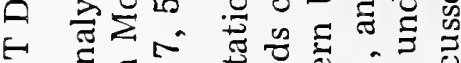

ए

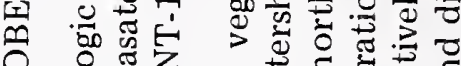

○

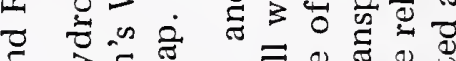

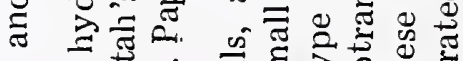

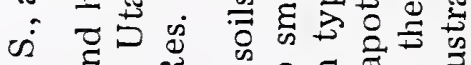

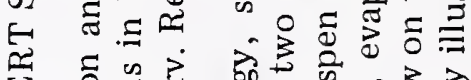

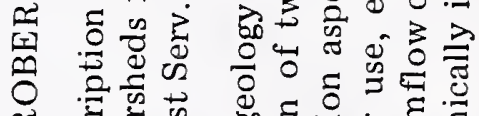

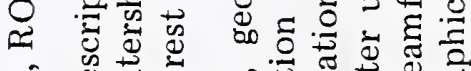

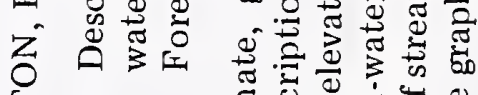

证

党 今.

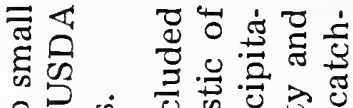

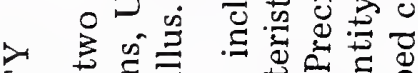

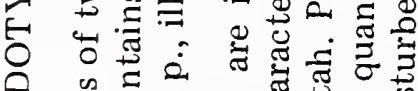

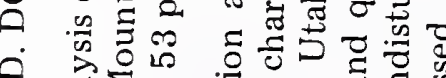

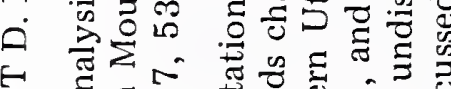

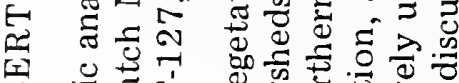

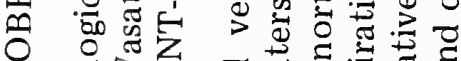

을 至

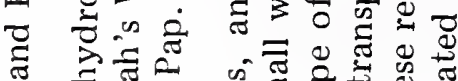

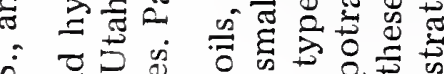

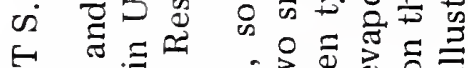

๘

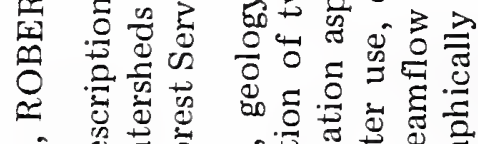

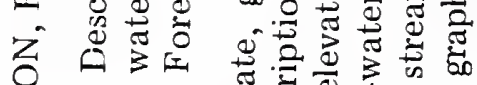

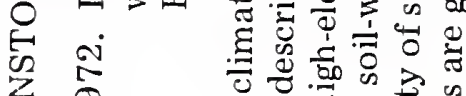

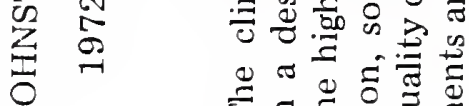

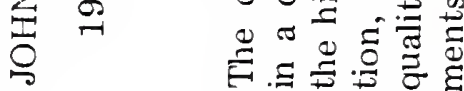

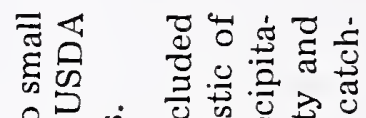

入

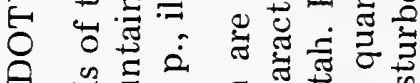

- 至吉

A

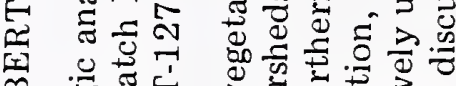

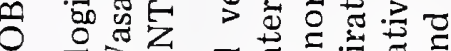

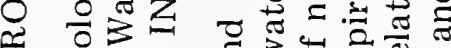

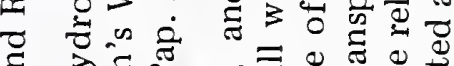

ส

$\therefore$ ठ

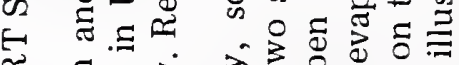

प

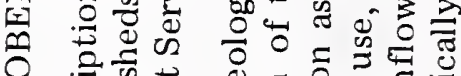

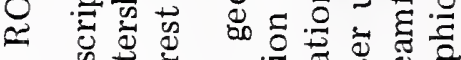

Z

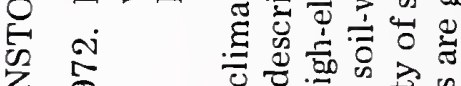

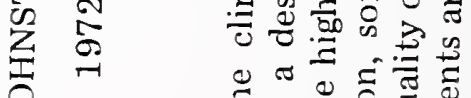

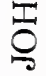

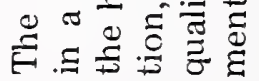

